\title{
26. MAGNETOSTRATIGRAPHY OF THE NORTH AOBA BASIN ${ }^{1}$
}

\author{
Xixi Zhao, ${ }^{2}$ Pierrick Roperch, ${ }^{3}$ and Laura B. Stokking ${ }^{4}$
}

\begin{abstract}
The goal of Ocean Drilling Program (ODP) Leg 134 was to study the tectonic history of the central New Hebrides Island Arc system (Vanuatu). ODP Sites 832 and 833 were drilled in the intra-arc North Aoba Basin. Volcanic sandstone and siltstone and clayey silty limestone make up most of the recovered basin-fill sediment. The magnetic susceptibility in the sediment is high, varying on average from 0.005 to 0.03 SI because of the high volcanic influxes derived either from erosion of volcanic rocks from nearby islands or from the output of active volcanoes. Determination of the timing of the tectonic and volcanic events recorded in the sedimentary sequences requires the establishment of a high-resolution stratigraphic framework. The magnetostratigraphic data presented here are based on a combination of shipboard whole-core pass-through cryogenic measurements, made at 5 -cm intervals on all archive core halves after alternating field (AF) demagnetization (usually $10 \mathrm{mT}$ ), and shipboard and post-cruise progressive AF and thermal demagnetization analyses of 466 (Site 832) and 715 (Site 833) discrete samples.

The volcanic-rich sediment yielded complex remanent magnetizations having widespread drilling-induced magnetic overprints. Detailed AF and thermal demagnetizations of discrete samples indicate that the volcanic sandstones have a stable, normal-polarity magnetization that is probably of viscous origin acquired during the late Brunhes Chron.

At Site 832, in the north central part of the basin, a major stratigraphic unconformity is found at 700 meters below sea floor (mbsf). Above the breccia unit that defines the unconformity, numerous slump structures have disturbed primary depositional remanent magnetizations, so a reliable magnetostratigraphy is not possible from 150 to $700 \mathrm{mbsf}$. The Brunhes/Matuyama boundary was not identified. Below the unconformity, a reliable magnetostratigraphic record from 700 to $825 \mathrm{mbsf}$ was obtained in silty limestone. In conjunction with biostratigraphic data, correlation of the magnetostratigraphic sequence with the geomagnetic polarity time scale indicates that the sediments were deposited from the late Miocene (Chron 5) to the Pliocene/Pleistocene boundary. The interpretation of the magnetostratigraphic record in turn suggests that the volcanic breccia unit accumulated during early Pleistocene time.

At Site 833, located on the eastern flank of the basin, the Brunhes/Matuyama boundary and the Jaramillo Subchron can be recognized from 200 to $260 \mathrm{mbsf}$. From 260 to $650 \mathrm{mbsf}$, numerous volcanic sandstone layers, which have relative high magnetic susceptibilities $(0.01-0.03 \mathrm{SI})$, record a predominant normal polarity of possibly viscous origin that makes the establishment of a reliable magnetostratigraphic record difficult. The Mammoth subchron tentatively has been recognized from 650 to $700 \mathrm{mbsf}$. The magnetostratigraphy at Site 833 implies a sedimentation rate of about $10 \mathrm{~cm} / \mathrm{k} . \mathrm{y}$. during the middle Pliocene, which is in contrast to the low sedimentation rate (about $1.5 \mathrm{~cm} / \mathrm{k} . \mathrm{y}$.) estimated at Site 832 for the same period.
\end{abstract}

\section{INTRODUCTION}

The primary objective of Leg 134 was the study of the collisional tectonic history of the central New Hebrides Island Arc system (Vanuatu) in the southwestern Pacific Ocean. Eastward subduction of the Australia-India Plate beneath the New Hebrides Island Arc has been active since the late Miocene. The complex tectonics of the New Hebrides Island Arc involve the d'Entrecasteaux zone (DEZ), which is composed of two aseismic ridges that are colliding with the central part of the arc (Collot, Greene, Stokking, et al., 1992). Rapid subduction of the North d'Entrecasteaux Ridge ( $2500 \mathrm{~m}$ high) uplifts a group of islands in the front- and backarc, with simultaneous subsidence of the intra-arc Aoba Basins (Collot et al., 1985).

In the North Aoba Basin, Sites 832 and 833 penetrated more than $1000 \mathrm{~m}$ of upper Miocene to Holocene volcaniclastic and carbonate sediment, as well as basaltic sills. Magnetic directions in these two sites were obtained by measuring archive half sections using the shipboard pass-through cryogenic magnetometer measurements and by progressive thermal and $\mathrm{AF}$ demagnetization experiments of discrete samples on shore.

More than 1000 discrete samples were selected to determine the characteristic directions. The measurement of discrete samples acts as a valuable calibration of the results obtained using the pass-through

${ }^{1}$ Greene, H.G., Collot, J.-Y., Stokking, L.B., et al., 1994. Proc. ODP, Sci. Results, 134: College Station, TX (Ocean Drilling Program).

${ }_{2}^{2}$ Earth Science Department, U.C. Santa Cruz, CA 95064, U.S.A.

${ }^{3}$ ORSTOM, BP 48, 06230 Villefranche-sur-Mer, France.

${ }^{4}$ ODP, Texas A\&M University, College Station, TX 77845, U.S.A. cryogenic magnetometer onboard the ship. The magnetic polarity patterns contained within cores from these two sites, when unambiguously correlated with the sequence of magnetic polarity chrons of the geomagnetic polarity time scale (GPTS) (Berggren et al., 1985), should serve as both an important tool for estimating age and for stratigraphic correlations between the two sites and as additional data that may help improve the calibration of the geomagnetic polarity chrons. In this paper we describe and discuss the paleomagnetic analysis of the sediment and volcanic rocks recovered from these two sites, focusing on the intervals that provided the most reliable data, and then interpret the polarity sequences used in conjunction with biostratigraphy and the GPTS to present a magnetostratigraphy for the two basin sites.

\section{SITE SETTING AND STRATIGRAPHY}

The site locations and tectonic history of the North Aoba Basin have been documented in detail in the 134 Initial Reports volume and appropriate papers (Collot, Greene, Stokking, et al., 1992; Greene et al., this volume) and are only briefly summarized here.

Site 832 is located at $14^{\circ} 47^{\prime} \mathrm{S}, 167^{\circ} 34^{\prime} \mathrm{E}$ in a water depth of $3089 \mathrm{~m}$ below sea level (mbsl). This site is centered on the flat basin floor of the North Aoba Basin, approximately $50 \mathrm{~km}$ northeast of the northern tip of the Queiros Peninsula of Espiritu Santo Island, and $45 \mathrm{~km}$ south of the active volcanic island of Santa Maria (Fig. 1). At Site 832, two holes were drilled that penetrated more than $1100 \mathrm{~m}$ of basin-fill deposits. Seven lithostratigraphic units were identified at Site 832. The uppermost lithostratigraphic Unit I is a 385.6-m-thick Pleistocene sequence of sandy to clayey volcanic silt with interbedded volcanic 


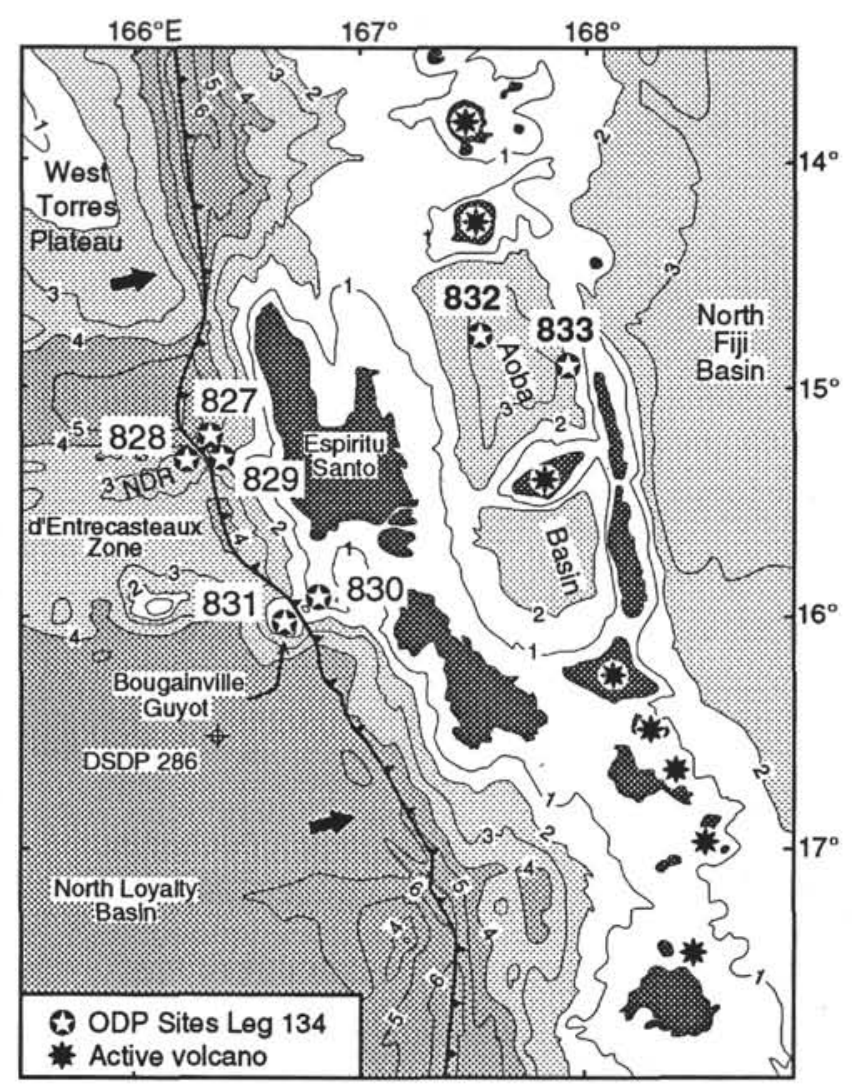

Figure 1. Regional bathymetry map of the New Hebrides Arc showing the location of Leg 134 drill sites (after Collot, Greene, Stokking, et al., 1991).

ash layers. Lithostratigraphic Units II (385.6-461.5 mbsf) and III (461.5-625.7 mbsf) correspond to calcareous mixed sediment, with substantial volcanic material in Unit II. Lithostratigraphic Unit IV (625.7-702 mbsf) is composed of Pleistocene or upper Pliocene partially lithified basaltic breccia. Unit V (702-865.7 mbsf) is composed of a Pliocene to upper Miocene silty limestone. The most relevant paleomagnetic results at Site 832 were obtained in this unit. Sandstone and breccias are found lower, in Units VI and VII.

Units II and III show numerous slump structures, whereas strata in Unit V are essentially flat lying. Normal faults with slickensides were observed in Unit V (Pelletier et al., this volume). However, the displacements of the faults are millimeters in magnitude and were interpreted as a response to bedding parallel extension. This small amount of deformation is not penetrative and should not significantly affect the remanent magnetization. Similar structural features were also observed at Site 833 in similar lithologic rocks.

Site 833 is located at $14^{\circ} 52^{\prime} \mathrm{S}, 167^{\circ} 52^{\prime} \mathrm{E}$, in a water depth of 2629 mbsl. This site is located on the lower northwestern flank of Maewo Island, about $24 \mathrm{~km}$ northwest of the northern tip of Maewo Island, and about $72 \mathrm{~km}$ southeast of the active volcanic island of Santa Maria. Two holes also were drilled at Site 833. Five lithostratigraphic units were defined. Like Site 832, nearly 400 m of Pleistocene sediment were recovered at Site 833. Lithostratigraphic Unit III (375.8-577.8 mbsf) is a thick upper Pliocene to lower Pleistocene volcanic sandstone and fine-grained basaltic breccia. Lithostratigraphic Units IV (577.8-830.3 mbsf) and V (830.3-1001.1 mbsf) are lower Pliocene to upper Pliocene mixed sediment with foraminiferal sandy volcanic siltstone. Basaltic sills are interlayered with calcareous silty volcanic claystone or siltstone. Formation MicroScanner (FMS) and structural data indicate that bedding is tilted about $10^{\circ}$ toward the west in most units. Slump structures are scattered but are especially well developed in the bottom part of the hole (Cores 134-833B-74R through -79R, 760-818 mbsf).
The North Aoba Basin underwent a major tectonic event during early Pleistocene or late Pliocene time, as indicated at Site 832 by the abrupt transition from horizontal, well-stratified, silty calcareous deposits to overlying slumped and coarse volcanic deposits. This tectonic event, marked by an angular unconformity in seismic reflection data, appears to be synchronous with the uplift of Espiritu Santo Island, which occurred about 2 Ma (Collot, Greene, Stokking, et al., 1992). Despite the occurrence of this tectonic event, the stratigraphic correlations between Sites 832 and 833 are not straightforward. Sediments at Site 833 are more coarse-grained than those at Site 832 and the welldefined breccia layer observed at Site 832 (Unit IV) is broader at Site 833 , with less marked lithologic contrasts. The Pliocene sequence at Site 833 is much thicker than its counterpart at Site 832. Variations in sedimentary thicknesses between Sites 832 and 833 suggest that the axis of the basin migrated westward during the Pleistocene. This migration may be contemporaneous with the Pleistocene uplift of the Eastern Belt.

\section{BIOSTRATIGRAPHY}

Age control in the sediment at both Sites 832 and 833 is primarily from nannofossil and planktonic foraminifer biostratigraphy. The biostratigraphy of the two basin sites was first described in Collot, Greene, Stokking, et al. (1992); updated biostratigraphic data for the drilling sites in North Aoba Basin were also obtained from R. Perembo and $\mathrm{S}$. Staerker (pers. comm., and this volume). A summary is given in Table 1. Detailed biostratigraphic interpretation is hindered by dilution from volcaniclastic sediment that results in nannofossil abundances fluctuating between common and rare.

The sediments at Site 832 were deposited during the following times: 0-600 mbsf, Pleistocene; 600-711 mbsf, early Pleistocene to late Pliocene; 711-769 mbsf, late Pliocene; 769-856 mbsf, early Pliocene, with the possibility that sediment from 817 to $856 \mathrm{mbsf}$ may be of late Miocene age, 924-962 mbsf earliest middle Miocene, and 962-972 mbsf latest early Miocene. A plot of sediment accumulation rate shows a change in slope near $700 \mathrm{mbsf}$, above which rates are $>100 \mathrm{~m} / \mathrm{m}$.y. and below which rates are about $50 \mathrm{~m} / \mathrm{m}$.y. (Collot, Greene, Stokking, et al., 1992).

Application of foraminiferal and nannofossil biostratigraphies at Site 833 was severely limited by the abundance of volcanic ash, volcaniclastic sediment, and turbidites. As a result, many samples were barren or contained only a few specimens that did not confirm ages. Despite this, planktonic foraminiferal zones N22 to N19 (Holocene to early Pliocene) were recognized in the sedimentary section at Site 833. A general age stratification was established and is as follows:

Table 1. Biostratigraphic datums, Holes 832B and 833B.

\begin{tabular}{lll}
\hline Biostratigraphic datum & $\begin{array}{c}\text { Age } \\
(\mathrm{Ma})\end{array}$ & $\begin{array}{c}\text { Depth } \\
\text { (mbsf) }\end{array}$ \\
\hline Hole 832B & & \\
LAD D. brouweri $(\mathrm{N})$ & 1.89 & $705.41-706.90$ \\
FAD G. truncatulinoides $(\mathrm{F})$ & 1.90 & 716.00 \\
LAD D. pentaradiatus (N) & 2.35 & $718.12-721.3$ \\
LAD D. surculus (N) & 2.42 & $724.31-725.8$ \\
LAD D. tamalis (N) & 2.65 & $735.21-740.33$ \\
LAD S. abies (N) & 3.45 & $746.58-747.74$ \\
FAD G. tumida $(\mathrm{F})$ & 5.20 & 839.00 \\
& & \\
Hole 833B & 1.30 & 252.00 \\
FAD P. finalis $(\mathrm{F})$ & 1.90 & 396.00 \\
FAD G. truncatulinoides $(\mathrm{F})$ & 3.10 & 646.00 \\
FAD G. tosaensis $(\mathrm{F})$ & 4.30 & 753.00 \\
FAD G. crassaformis $(\mathrm{F})$ & 5.20 & 938.00 \\
FAD G. tumida $(\mathrm{F})$ & & \\
\hline
\end{tabular}

Note: $\mathrm{N}=$ nannofossil $; \mathrm{F}=$ foraminifer $\mathrm{FAD}=$ first-appearance datum; LAD = last-appearance datum. 
Pleistocene, between 0 and 375.0 mbsf; late Pliocene, between 375.0 and $635.6 \mathrm{mbsf}$; and early Pliocene, between 635.6 and $945.0 \mathrm{mbsf}$. The interval between 193.1 and $375.0 \mathrm{mbsf}$ (Samples 134-833B-12R$\mathrm{CC}$ to $-31 \mathrm{R}-\mathrm{CC}$ ) is early Pleistocene (early N22) in age, based on the scattered co-occurrence of Globorotalia tosaensis s.1. and Globorotalia truncatulinoides, along with Globorotalia tumida tumida.

\section{LABORATORY AND ANALYTICAL METHODS}

\section{Sampling}

Discrete samples in soft sediment were taken using oriented standard plastic sampling boxes $\left(7 \mathrm{~cm}^{3}\right)$. To reduce the deformation of the sediment, cores were cut using a thin stainless-steel spatula before pressing the plastic sampling boxes into the sediment. Minicores ( 2.5 $\mathrm{cm}$ diameter, 2.3 to $2.5 \mathrm{~cm}$ in length) were drilled from lithified sedimentary rocks and igneous rocks using a water-cooled nonmagnetic drill bit attached to a standard drill press. Obvious slumped or disturbed intervals were generally avoided, but a few samples were taken to investigate the origin of the remanent magnetization. A total of 466 paleomagnetic samples were obtained from Site 832, and 715 samples were collected from Site 833 .

\section{Magnetic Measurement Procedures}

The paleomagnetic data presented here are of two different types: those obtained using the shipboard pass-through cryogenic magnetometer and those derived from measurements of discrete samples. In the shipboard pass-through system, natural remanent magnetization (NRM) measurements of sediment and rocks were performed by passing continuous archive-half core sections through a $2 \mathrm{G}$ cryogenic magnetometer; these were taken at intervals of either 5 or $10 \mathrm{~cm}$ along the core and after AF demagnetization at 5, 10, and $15 \mathrm{mT}$. Most sections were $\mathrm{AF}$ demagnetized at $10 \mathrm{mT}$ and measured at $5-\mathrm{cm}$ intervals. Some discrete samples ( 145 samples from Site 832 and 133 samples from Site 833) were measured and demagnetized using shipboard equipment. Magnetic measurements of discrete samples in shorebased studies were performed using a $2 \mathrm{G}$ cryogenic magnetometer and a Schonstedt spinner magnetometer housed in a field-free room in the paleomagnetic laboratory at the University of California at Santa Cruz (Site 832), and using a Molspin spinner in the paleomagnetic laboratory in ORSTOM, Villefranche-sur-Mer, France (Site 833). Both standard thermal and AF demagnetization experiments were conducted using Schonstedt and Molspin equipment to evaluate the directional stability and coercivity/unblocking temperature spectra of each sample. Isothermal remanent magnetizations (IRM) are remanences acquired in a strong direct current (DC) field and were given with a Bruker electro-magnet. Anhysteretic remanent magnetizations (ARM) were given with the Schonstedt AF demagnetizer in a DC field of $45 \mathrm{mT}$ and a peak AF of $95 \mathrm{mT}$.

\section{Analysis of Directions}

All samples were step-wise demagnetized, and a vector demagnetization diagram (Zijderveld, 1967) was used to identify the different components of magnetization. Magnetic components were determined by fitting least-squares lines to segments of the vector demagnetization plots that were linear in three-dimensional space ("the principal component analysis" of Kirschvink, 1980).

\section{MAGNETIC STABILITY AND RELIABILITY OF PALEOMAGNETIC DATA}

\section{Whole-core Pass-through Measurements}

One of the major experimental requirements in paleomagnetic research is to isolate the characteristic remanent magnetization (ChRM) by selective removal of any secondary remanences. Pass-through cryogenic paleomagnetic records have a high sampling resolution (usually
$5 \mathrm{~cm}$ ), but the low level AF demagnetization (usually $10 \mathrm{mT}$ ) allowed on ODP archive halve cores does not always ensure a complete removal of secondary magnetizations. In Figure 2, we summarize the NRM intensities and inclinations, both before and after $10 \mathrm{mT} \mathrm{AF}$ demagnetization, observed in rotary cores from Holes 832B and 833B. Stronger intensities of remanent magnetization were observed at Site 833 than at Site 832, and the difference also was observed in the distribution of susceptibility values (Fig. 2). On average, sediment recovered at Site 833 is richer in volcanic siltstone and sandstone than sediment at Site 832. However, no difference in the distribution of inclinations is seen between the two sites. At both sites, NRM inclinations are strongly biased toward high negative inclinations. Upon demagnetization to $10 \mathrm{mT}$, a shift toward shallower inclinations occurs, but the distributions still are not centered on the expected geocentric axial dipole fields (around $-30^{\circ}\left[+30^{\circ}\right]$ for a normal [reversed] polarity). Most of the data are from rock units that are of Pliocene to middle Pleistocene age, which implies that both polarities should have been recorded. Although most of the drilling-induced magnetization was removed by $\mathrm{AF}$ demagnetization at $10 \mathrm{mT}$, the bias in the distribution of inclination values indicates that a residual drilling-induced magnetization and viscous magnetization acquired during the last period of normal polarity are present in the pass-through records.

The pervasive remagnetization imparted by coring is commonly encountered, as noted during previous legs (Schneider and Kent, 1990). From various observations made aboard ship (see "Explanatory Notes," Collot, Greene, Stokking, et al., 1992, Fig. 8, p. 78), we found that the remanent magnetic field of a steel coring barrel could be imparted on the sediment contained within it. This remagnetization most severely affected the external portions of the cores (presumably because the outside of the core is physically closer to the magnetized core barrel). During standard drilling procedures, two core barrels are used. One is lowered into the pipe for recovery of the next core, while the previous core in the plastic core liner is taken out of the other core barrel. Figure 3 shows the effect of alternating core barrels upon the intensity of the NRM magnetizations of discrete samples. Intensities of NRM in discrete samples from even-numbered cores are higher than in odd-numbered cores. This difference disappears after 10-mT $\mathrm{AF}$ demagnetization. Thus, the magnetic field from a magnetized core barrel seems to be responsible for the remagnetization process and not the drill string or pipe. The use of stainless steel core barrels would perhaps reduce the acquisition of the drilling-induced magnetization. The drilling overprint is more important in volcanic-rich siltstone and sandstone than in less magnetic calcareous units (Fig. 4), for which a reverse polarity pattern is clearly defined by both pass-through and discrete measurements.

\section{AF and Thermal Demagnetization of Discrete Samples}

To investigate the nature of the remanent magnetization of the discrete samples, all samples were step-wise AF or thermally demagnetized. Demagnetization demonstrates that the remanent magnetization is the sum of three magnetizations: the characteristic primary magnetization of either normal or reversed polarity, a viscous overprint acquired during the last normal Brunhes Chron, and an upward, steep, drilling-induced overprint.

The drilling-induced overprint was generally removed by AF demagnetization at 5- to $10-\mathrm{mT}$ while thermal demagnetization (TH) up to $300^{\circ} \mathrm{C}$ was necessary to remove the steep secondary magnetization (Fig. 5). Although AF is more efficient than TH in removing the drilling overprint, we found that removal of the viscous overprint was better accomplished through thermal demagnetization. For example, Samples 134-833B-26R-1, 45-47 cm, and -26R-1, 50-52 cm, are from the same piece, and the primary reverse magnetization is better isolated using $\mathrm{TH}$ than $\mathrm{AF}$ demagnetization (Fig. 6). Due to high magnetic susceptibilities and low intensities of the remanent magnetization (low Koenigsberger ratios), the acquisition of spurious magnetizations during AF demagnetization such as anhysteretic, gyro- 
Site 832
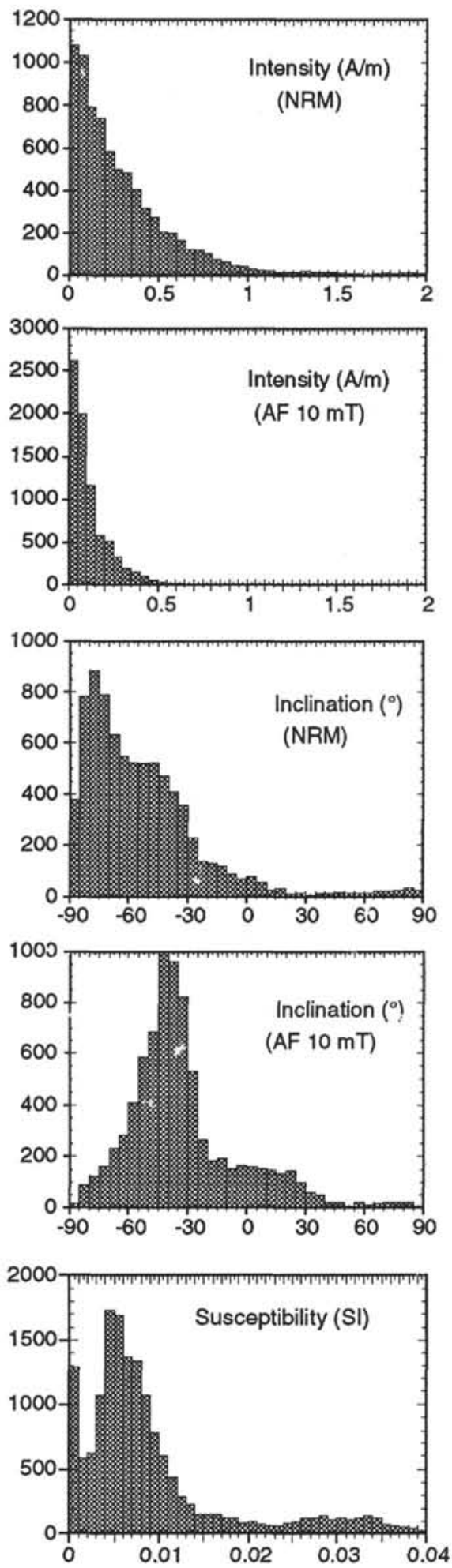

Site 833
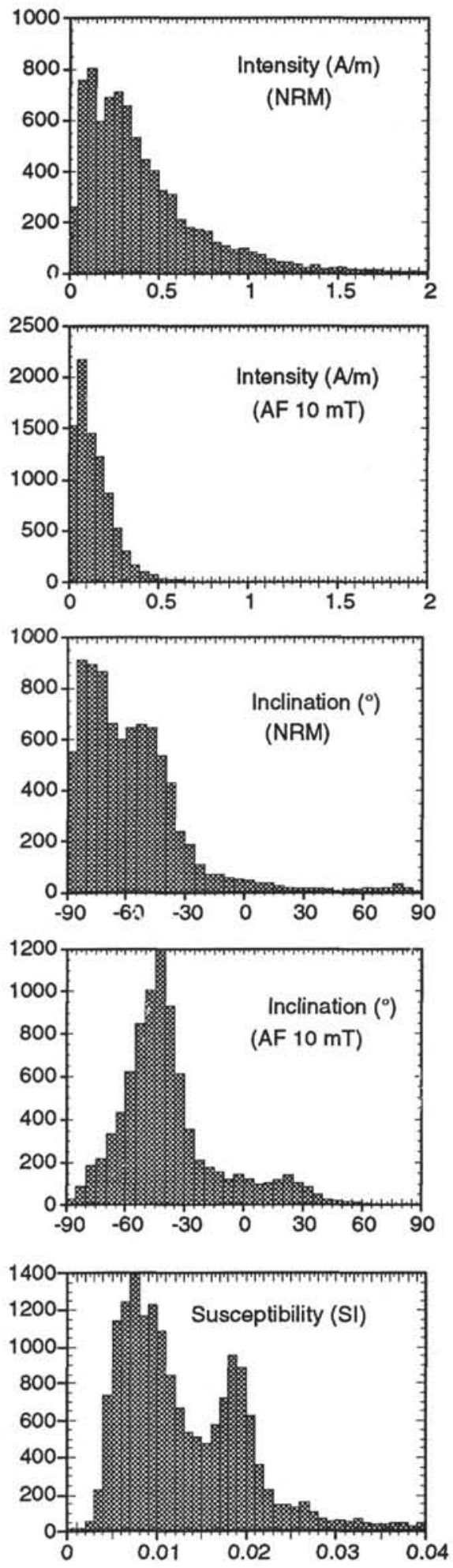

Figure 2. Comparison of magnetic data obtained from pass-through shipboard magnetometer and susceptibility meter for Sites 832 and 833 . Vertical axes show number of samples. 


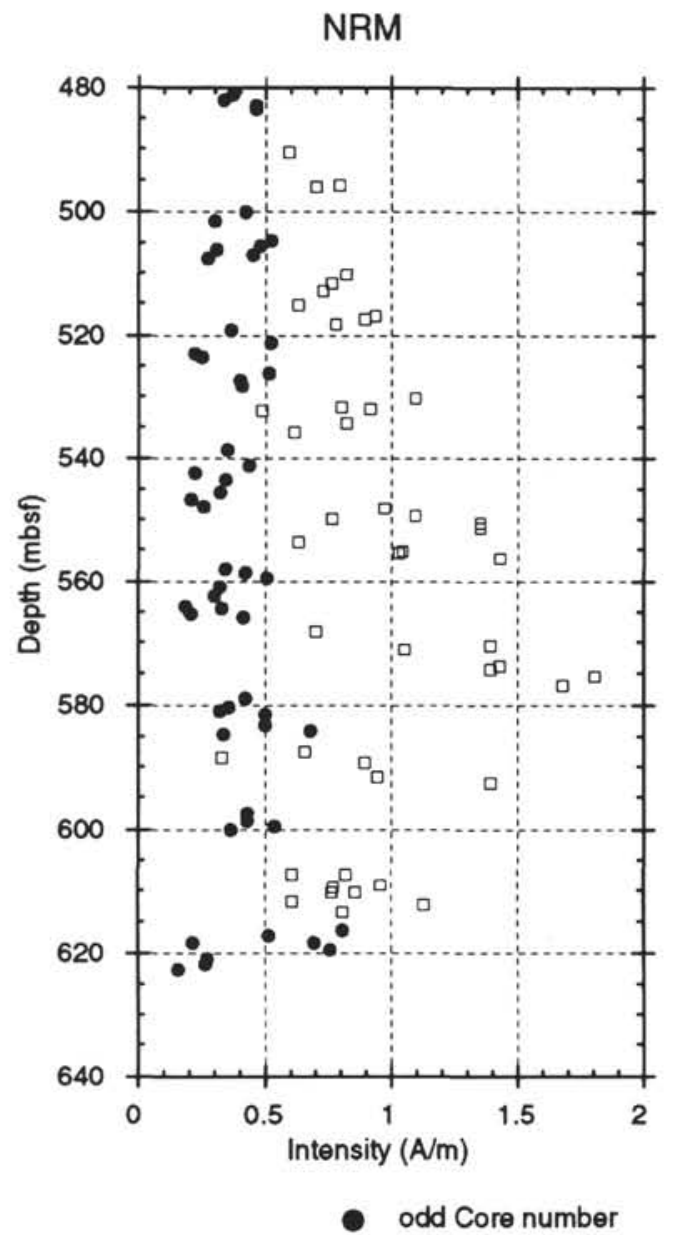

AF demagnetized (10 $\mathrm{mT})$

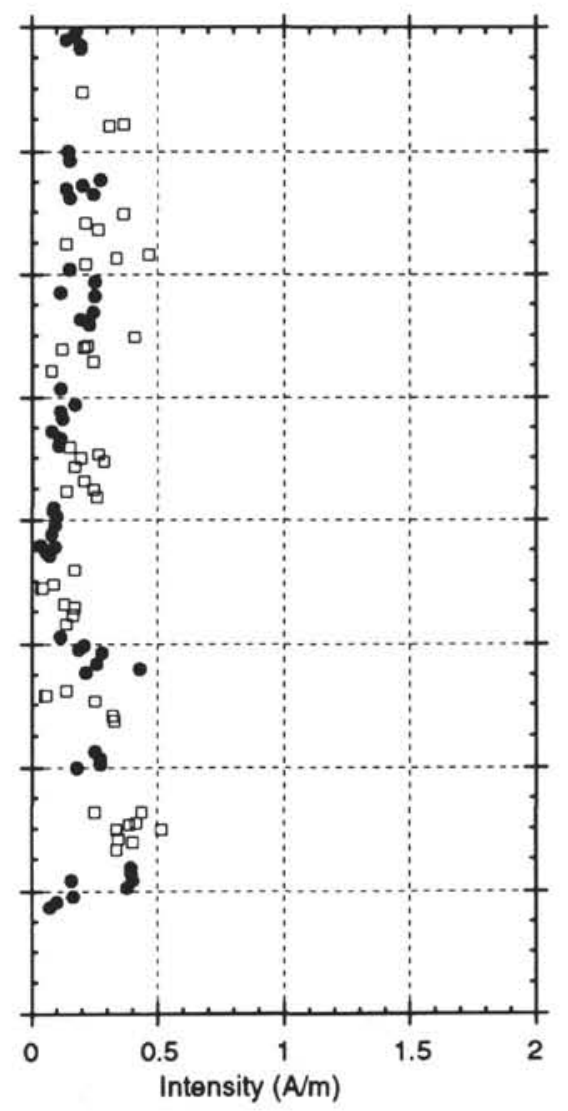

even Core number

Figure 3. Variation in the drilling-induced magnetization overprint in different core barrels from successive cores in Hole $833 \mathrm{~B}$ at the depth interval $480-640 \mathrm{mbsf}$. NRM intensity is significantly higher in even-numbered cores although there is no significant difference after AF demagnetization at $10 \mathrm{mT}$.

magnetic, or rotational remanent magnetizations (ARM, GRM, RRM) was often observed at AF peak fields higher than $50 \mathrm{mT}$. Thus, the determination of the magnetization carried by high-coercivity magnetic grains was hindered.

Demagnetization of discrete samples also shows that the remanent magnetization is strongly dependent upon the lithology. A good example is given by samples from Core 134-833B-26R (Fig. 6). Calcareous clayey volcanic siltstone beds alternate with vitric silty volcanic sandstone layers. Results of AF and TH demagnetizations for eight samples taken from Core 134-833B-26R are shown in Figure 6; in each section (134-833B-26R-1, -26R-2, -26R-3), all selected samples belong to the same piece and have the same relative orientation. AF demagnetization of samples taken in the sandstone indicates a single component of magnetization of normal polarity, while $\mathrm{AF}$ and $\mathrm{TH}$ demagnetizations of calcareous siltstone reveal a reversed component. Antipodal relative declinations within the same piece imply that the magnetization is not modified by physical disturbances, such as an undetected slump. AF and TH demagnetizations performed in two specimens from a sandstone layer in Section 134-833B-26R-3 clearly demonstrate that the single component isolated in $\mathrm{AF}$ is not primary. Upon $\mathrm{TH}$ demagnetization (Sample 134-833B-26R-3, 89-91 cm, Fig. 6), the magnetization shifts toward a positive inclination, but the primary characteristic direction is not clearly defined because the unblocking temperatures of the secondary magnetizations are widely distributed up to $400^{\circ} \mathrm{C}$. These high unblocking temperatures suggest that the magnetization is not only viscous, but may have been acquired during late diagenetic processes of Brunhes age. Thus, if the normal component of magneti- zation isolated by AF demagnetization is interpreted as a primary remanence then it would imply a succession of apparent reversals and gives a misleading magnetostratigraphic signal. Several other such examples were observed at Site 832 and particularly at Site 833, where the sedimentary sequence shows numerous sandstone beds interlayered with more clayey and calcareous siltstone. However, no difference can be seen in the acquisition of IRM and in the AF demagnetization spectrum of ARM among samples from calcareous and sandstone layers (samples from Core 134-833B-26R, Fig. 7). Thus, there is no significant difference in magnetic mineralogy between the different samples, and the different NRM behaviors are probably related to differences in deposition. Measurements of the anisotropy of magnetic susceptibility indicate that calcareous beds have an oblate shape fabric coplanar with the stratification while sandstone layers have no organized fabric (Roperch et al., this volume). The rapid deposition of coarse-grained sandstone prevented the acquisition of a detrital remanent magnetization.

\section{MAGNETIC RESULTS}

\section{Hole 832A}

Most sediment recovered at Hole $832 \mathrm{~A}$ are unlithified sandy to clayey volcanic silt. Pass-through measurements indicate that remanent magnetization in Cores $134-832 \mathrm{~A}-1 \mathrm{H}$ to $-11 \mathrm{H}(0-81.5 \mathrm{mbs})$ after $\mathrm{AF}$ demagnetization at $10 \mathrm{mT}$ is of normal polarity, with intensities ranging from about 0.1 to $0.3 \mathrm{~A} / \mathrm{m}$. Characteristic magnetizations of the corresponding discrete samples were easily identified from the 


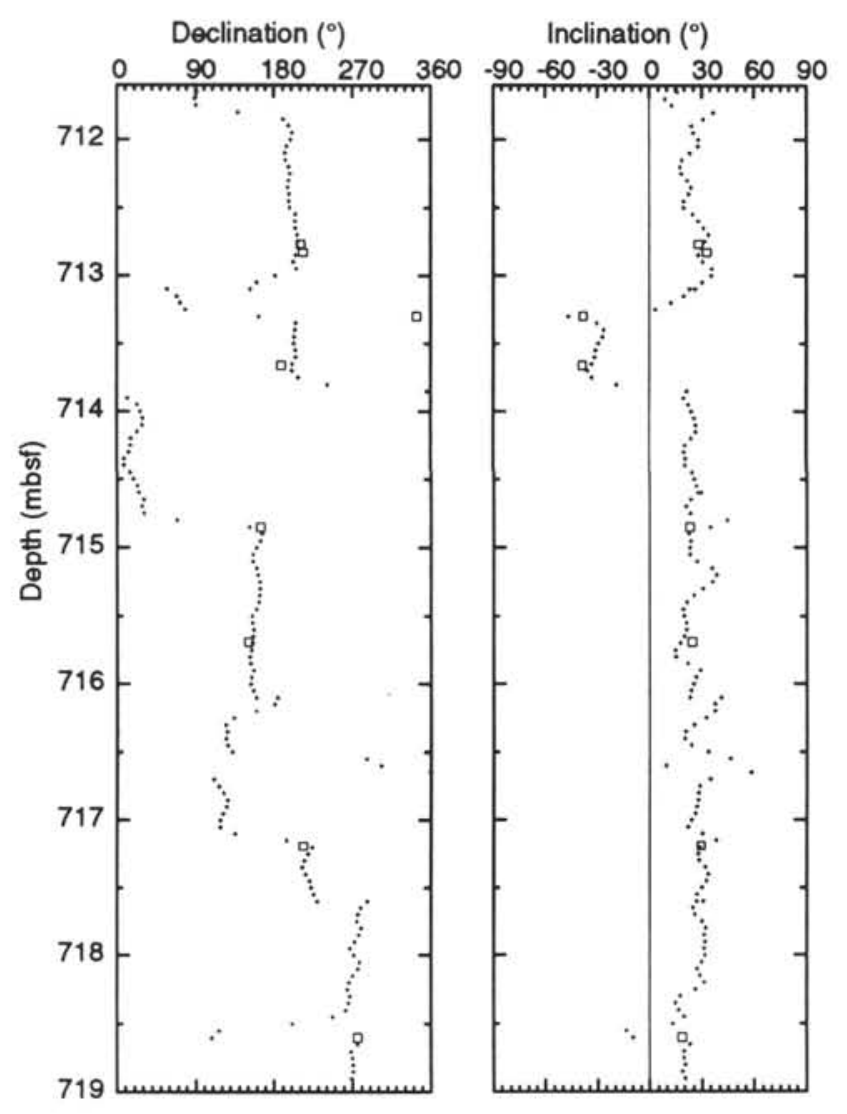

Figure 4. Example of pass-through cryogenic magnetometer data (solid) and discrete measurements (open squares) in silty calcareous limestone. Note the short interval of negative inclination which has been interpreted as the record of one of the Réunion events.

orthogonal demagnetization diagrams and the secondary magnetization generally can be removed by AF demagnetization at $20 \mathrm{mT}$. Although recovery was poor in Cores $132-832 \mathrm{~A}-12 \mathrm{H}$ to $-26 \mathrm{X}$ (91.5$206.2 \mathrm{mbsf}$ ), all paleomagnetic results of available samples show normal polarity.

\section{Hole 832B}

Seven distinct lithostratigraphic units were identified at Hole $832 \mathrm{~B}$. Paleomagnetic results at Hole $832 \mathrm{~B}$ reflect the lithologic variations. Thus, the paleomagnetic data from Hole $832 \mathrm{~B}$ are discussed according to the major lithologic changes observed in the cores and summarized below.

1. Lithostratigraphic Subunit IB, and Units II and III (Cores 134832B-1R through -50R, from 144.4 to $625.7 \mathrm{mbsf}$ ) are Pleistocene silty volcanic clay and clayey volcanic silt with foraminifers and calcareous nannofossils, sandstone, and siltstone. Step-wise TH and AF demagnetizations were performed on 137 discrete samples. The inclinations in these cores, although scattered, are predominantly negative, indicating a normal polarity for these cores. However, several samples exhibited demagnetization curves that missed the origin of the vector plots. Slumps are abundant in these units. The magnetization of the slumped sediment is difficult to interpret in the absence of core orientation information. As shown in Figure 8, the high-temperature component in Sample 134-832B-31R-1, 96-98 cm, corresponds to a direction with positive inclination. In contrast, Samples 134-832B$31 \mathrm{R}-2,145-147 \mathrm{~cm}$, and $-31 \mathrm{R}-3,8-10 \mathrm{~cm}$, taken from another slump having subvertical structures, have identical demagnetization paths with a negative inclination while direction is constant at low and high
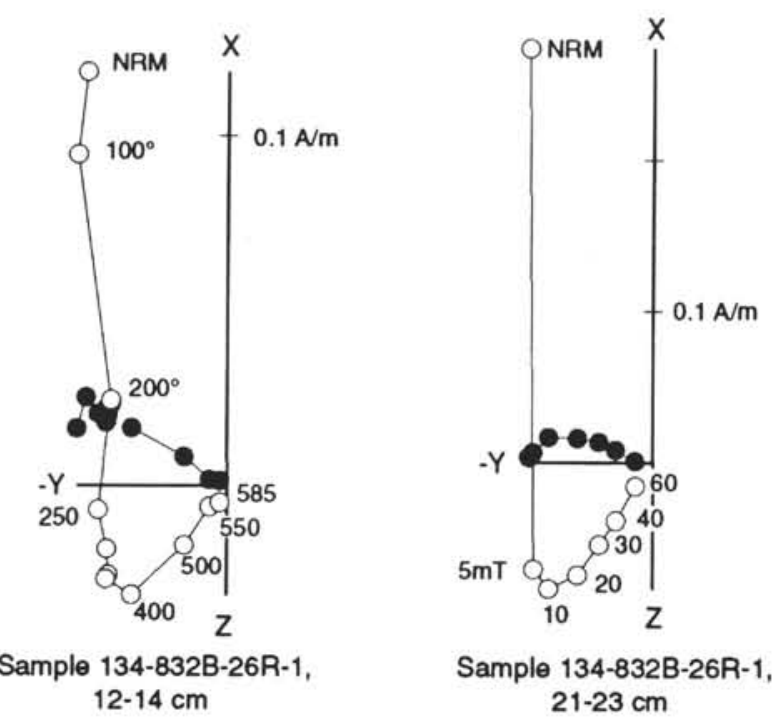

Figure 5. Examples of TH and AF demagnetization for two samples from a single rock piece from Core 134-832B-26R. A vertical upward secondary magnetization has been removed by $\mathrm{AF}$ and $\mathrm{TH}$ demagnetization. This secondary magnetization was interpreted as a drilling-induced magnetization having low-to-intermediate thermal unblocking temperatures. The characteristic primary magnetization has positive inclination, suggesting sediment deposition during a period of reversed polarity. Open symbols = projections onto the vertical plane and filled circles = projections onto the horizontal plane. NRM $=$ natural remanent magnetization.

unblocking temperatures. The origin of this apparently dual polarity magnetization is unclear.

There is only one indication of a short reversed polarity, found in Core 134-832B-26R (385.6-395.3 mbsf) where no obvious physical disturbance was observed. There is a recovery gap of about $27 \mathrm{~m}$ above this core. The sediments in the upper part of Core 134-832B$26 \mathrm{R}$ have an apparently reversed magnetization, as indicated by both pass-through and discrete sample measurements (Fig. 5). Biostratigraphic data indicate that the sediments were deposited in the middle Pleistocene and the observed reversed magnetization may indicate that these sediments are older than the Brunhes/Matuyama (B/M) boundary (0.78 Ma, see Baski et al., 1991). The lower part of Core 134-832B-26R is a gray sed-igneous breccia, which does not show the reversed component. Therefore, the evidence for a reversed magnetization is supported only by results from less than $1 \mathrm{~m}$ of recovered materials.

2. Lithostratigraphic Unit IV (Cores 134-832B-51R to $-58 \mathrm{R}$, $625.7-702.0 \mathrm{mbsf}$ ) consists of basaltic breccia and volcanic sandstone and siltstone. Very high magnetic susceptibilities characterize this unit. Forty discrete samples were collected from these cores. After removal of the steep upward drilling overprint, only a component of normal polarity was recovered. However, this component of magnetization is very soft and has low unblocking temperatures. Detailed demagnetization results from eight samples taken in Core 134-832B$53 \mathrm{R}$ show very similar characteristic directions, yet these sections exhibited different faulting, convoluted, and steeply dipping beds. The very similar results from these sections then would indicate that the magnetization post-dates all the observed sedimentary structures and tectonic activities, failing the "within-hole" fold test.

3. Lithostratigraphic Unit V (Cores 134-832B-59R through -75R, 702.0-865.7 mbsf). As mentioned previously, a major change in lithology occurs at the top of Core 134-832B-59R near 700 mbsf, which also coincides with an unconformity identified in seismic reflection profiles (Fisher et al., 1988; Greene and Johnson, 1988). The sediments below this depth consist predominantly of light gray to dark greenish-gray limestone and volcanic sandstone that do not show slump or other sedimentary structures. The Formation MicroScanner 

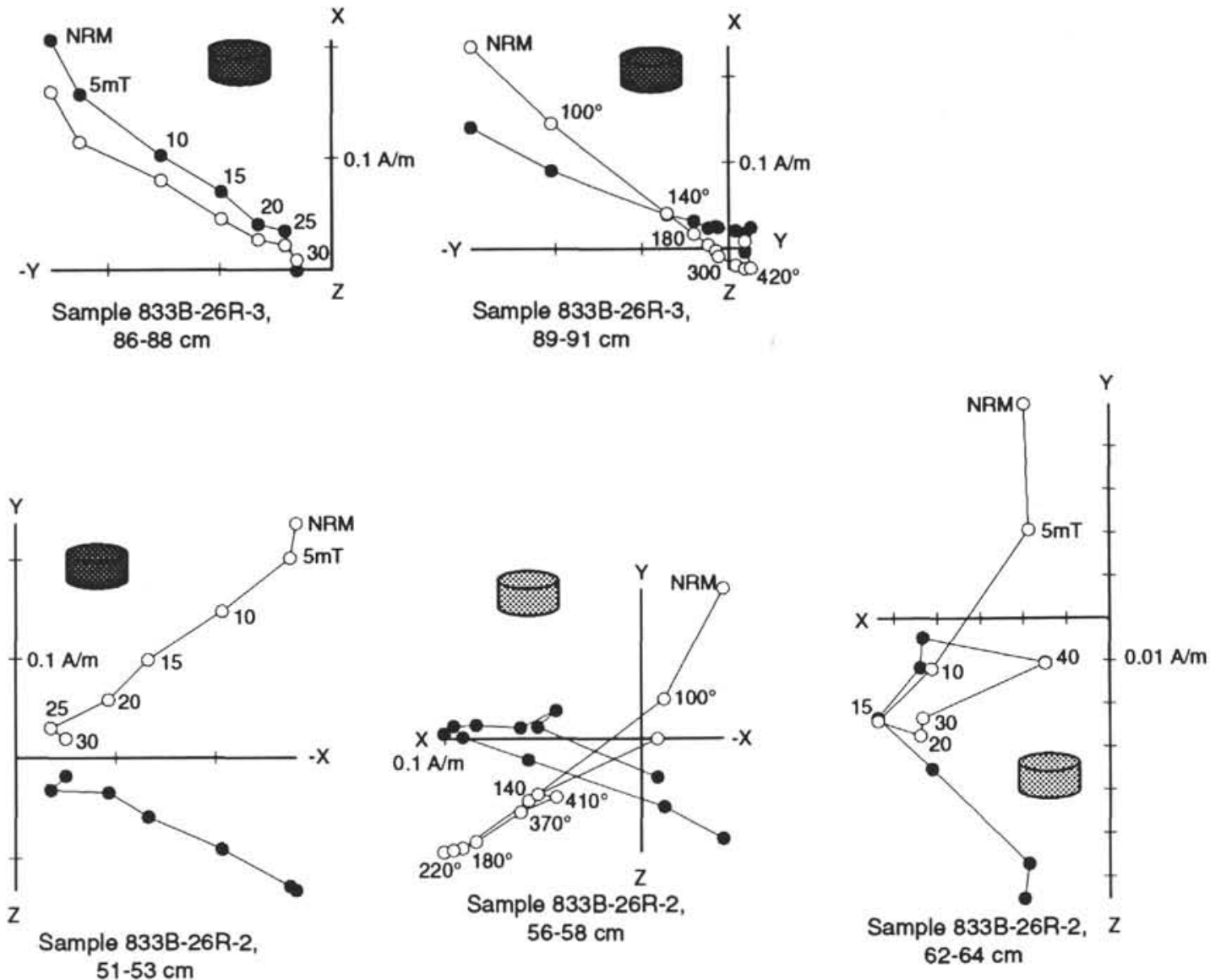
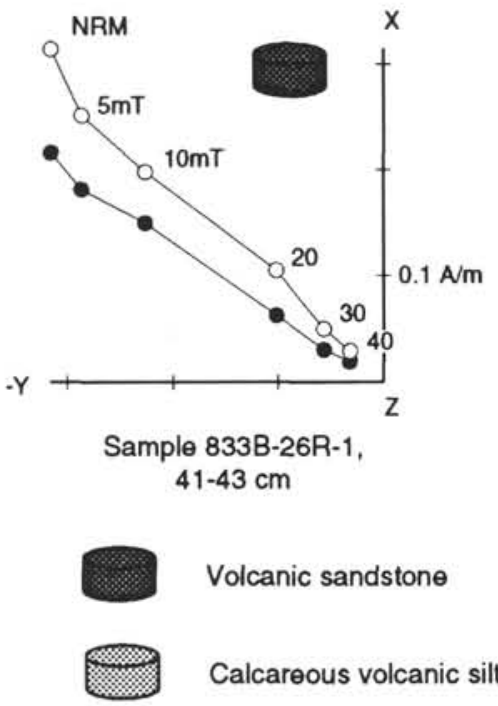

Volcanic sandstone

Calcareous volcanic siltstone

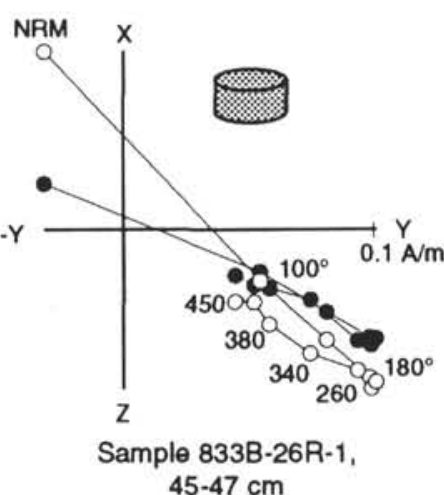

$45-47 \mathrm{~cm}$

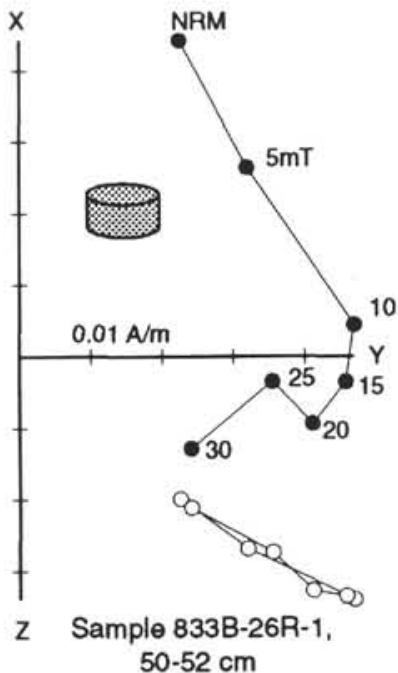

Figure 6. Orthogonal AF and TH demagnetization diagrams in volcanic sandstone and calcareous clayey volcanic siltstone from Core 134-833B-26R. In each section, samples were taken from the same piece and have the same relative orientation. Normal and reversed magnetizations are antipodal. Samples in volcanic sandstone show only a normal polarity, whereas samples in calcareous volcanic siltstone have predominantly a reversed magnetization. Symbols and conventions as in Figure 5.

(FMS) images indicate that these rocks are finely laminated with bedding planes that are horizontal or dip slightly toward the east. The best paleomagnetic results at Site 832 have been obtained in this lithostratigraphic unit. Pass-through measurements revealed several intervals of magnetic polarity changes in this unit, which were confirmed by detailed $\mathrm{AF}$ and $\mathrm{TH}$ demagnetization of 152 corresponding discrete samples. In most cores, polarity sense can be assigned with reasonable assurance on the basis of the inclination determined from discrete samples (Fig. 9). Moreover, when cores contain long, continuous pieces, changes in inclination may sometimes be correlated with near- $180^{\circ}$ variation in declination, adding confidence to the polarity determinations (Fig. 9). This positive "antipodal test" argues strongly 

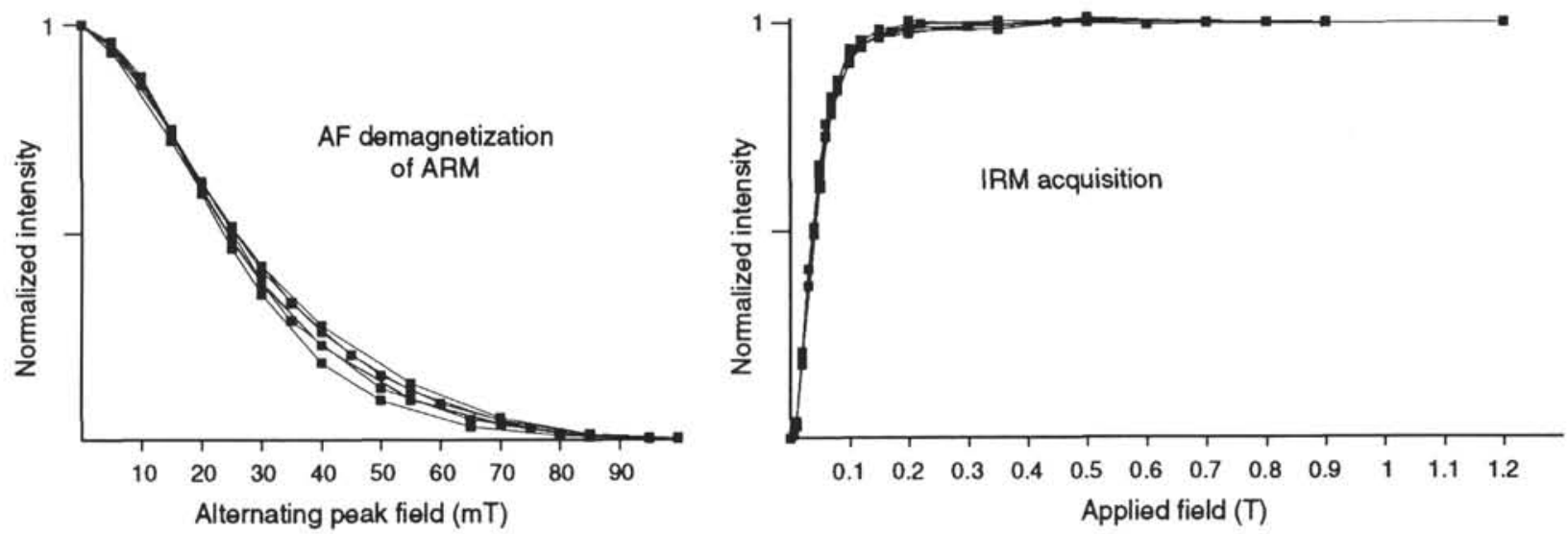

Figure 7. AF demagnetization of ARM and acquisition of IRM for six samples from Core 134-833B-26R.

that the polarity zones represent magnetizations established near the time of deposition, although this test is not sufficient by itself. Passthrough whole-core measurements after AF demagnetization at $10 \mathrm{mT}$ and data from discrete samples are plotted for three depth intervals that cover most of Unit V (Figs. 10A, 10B, and 10C). Changes in the sign of the inclination from negative to positive are correlated with a large decrease in the intensity of the remanent magnetization and a significant increase in the dispersion of the paleomagnetic results. These correlations may also reflect the effect of incomplete removal of a late viscous overprint at $10-\mathrm{mT}$ demagnetization. (The magnetostratigraphic record will be further discussed in the magnetostratigraphy section.)

4. Lithostratigraphic Unit VI (Cores 134-832B-77R to -84R, 865.7$952.6 \mathrm{mbsf}$ ) comprises lithified volcanic sandstone that becomes coarsergrained from top to bottom. Both pass-through cryogenic measurement and 37 discrete samples from these cores showed predominantly negative inclinations. However, the low unblocking temperatures and the poor stability of the magnetization suggest that the NRM might be dominated by an unremoved normal polarity overprint.

5. Lithostratigraphic Unit VII (Cores 134-832B-85R to $-100 \mathrm{R}$, 952.6-1106.7 mbsf) consists mainly of basaltic breccia and conglomerate. The NRM intensities and magnetic susceptibilities in this unit are significantly lower than those of the overlying units which probably reflects an increase in the amount of alteration of magnetic minerals. The volcanic breccia of the lowest layers of this unit were probably the product of submarine volcanism, because they contain a matrix with abundant alteration products such as palagonite, chlorite, clay minerals, and zeolite. The magnetization is dominated by soft secondary magnetizations and, thus, we consider that this unit does not contain a reliable magnetostratigraphic record.

\section{Hole 833A}

Like their counterparts at Site 832 , sediments recovered at Hole $833 \mathrm{~A}$ are interbedded unlithified volcanic ashes and sandy to clayey volcanic silts (lithostratigraphic Unit I). Both pass-through cryogenic measurement and progressive AF demagnetization on discrete samples show that remanent magnetizations in Cores $134-833 \mathrm{~A}-1 \mathrm{H}$ to $-8 \mathrm{H}(0-58.1 \mathrm{mbsf})$ are of normal polarity. Sediments were disturbed and recovery rate was poor from 58.1 to 199.5 mbsf (Cores 134$833 \mathrm{~A}-9 \mathrm{H}$ to $-26 \mathrm{X})$, but the inclinations of discrete samples from these cores show no evidence for reversed polarity.

\section{Hole 833B}

Five lithostratigraphic units have been described at Site 833 . Demagnetization behavior varied with the lithostratigraphic units. Thus, paleomagnetic results again are discussed according to relation to lithostratigraphic units.
1. Lithostratigraphic Unit II (Cores 134-833B-1R through -31R, from 77.4 to $375.8 \mathrm{mbsf}$ ) is composed of alternating layers of highly bioturbated sedimentary rock interbedded with calcareous clayey volcanic siltstone and clayey volcanic silt. All inclinations of Cores 134$833 \mathrm{~B}-1 \mathrm{R}$ to $-13 \mathrm{R}$ are negative, indicating normal polarity from 77.4 to about 202.8 mbsf. Several intervals of alternate apparent polarities can be found below a depth of $210 \mathrm{mbsf}$, from Cores 134-833B-14R through -31R. However, changes in the sign of the inclination appear to correlate with changes in lithology between volcanic calcareous siltstone and sandstone as shown in Figure 6. Detailed TH demagnetizations demonstrate that the normal component magnetization isolated by AF demagnetization in sandstone is probably a secondary viscous remanent magnetization (VRM) overprint.

2. Lithostratigraphic Unit III (Cores 134-833B-32R to $-54 \mathrm{R}$, $375.8-577.7 \mathrm{mbsf}$ ) is mostly composed of fine to coarse-grained volcanic sandstone and basaltic breccia. The inclinations observed in measurements obtained from both archive-half sections (after AF demagnetizations at $10 \mathrm{mT}$ ) and discrete samples (progressive $\mathrm{AF}$ and $\mathrm{TH}$ demagnetization on more than 90 samples) are predominantly negative, suggesting a normal polarity for these cores. Comparison of data obtained from archive-half sections measured using the passthrough cryogenic magnetometer and discrete samples are shown for Cores 134-833B-38R and -39R (Fig. 11). The consistency of results between both sets of measurements does not indicate whether a primary magnetization was preserved or whether these sediments only recorded a present-day normal viscous overprint. In Core 134-833B$39 \mathrm{R}$, thin layers of chloritic claystone with corresponding low magnetic susceptibility values are interbedded with the sandstone. The only evidence for a reversed magnetization was found in one discrete sample at $444.1 \mathrm{mbsf}$ in the chloritic claystone layer or clast. Although the thin beds of claystone appear to have an almost horizontal layering, they may correspond to large clasts incorporated in the sandstone. If these layers are really interbedded in the sandstone, the reverse magnetization, observed in one discrete sample at $444 \mathrm{mbsf}$, is an argument for deposition of the sandstone during a period of reversed polarity. Alternatively, if the claystones are displaced clasts, then deposition during a period of normal polarity cannot be rejected. Biostratigraphic analyses indicate a relatively higher sedimentation rate for this interval $(\sim 300 \mathrm{~m} / \mathrm{m} . \mathrm{y}$.) and so the absence of reversal does not necessarily rule out the possibility that a primary magnetization was recorded: the sandstone may have been deposited during the normal polarity Gauss Chron or Olduvai Subchron. In some samples, the moderate to good stability of the magnetization may favor a primary origin (Fig. 12). However, the preferred interpretation is that the normal component is a VRM overprint with a relatively long relaxation time.

3. Lithostratigraphic Unit IV (Cores 134-833B-55R to -81R, 577.8$830.3 \mathrm{mbsf}$ ) consists of fine-grained volcanic sandstone and siltstone interbedded with calcareous fine siltstone and claystone. From 577.8 


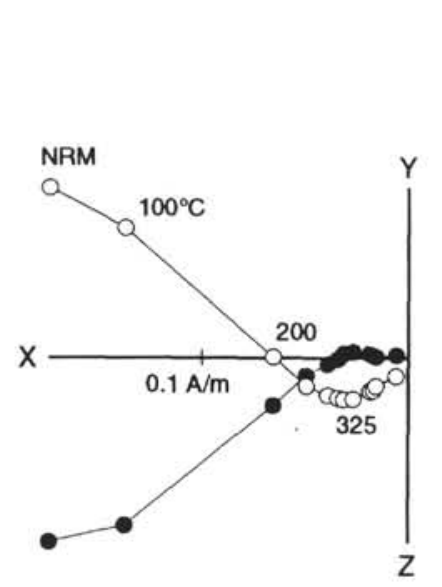

Sample 134-832B-31R-1, $96-98 \mathrm{~cm}$

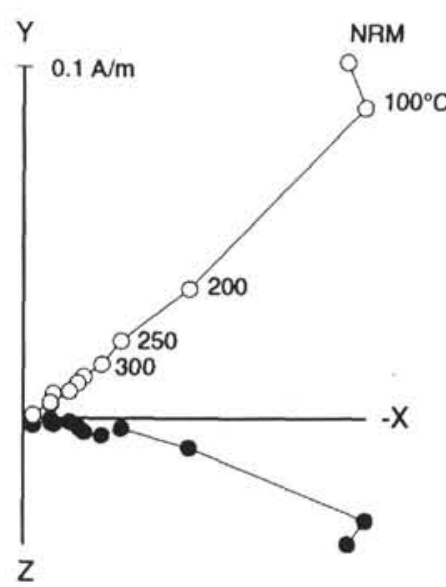

Sample 134-832B-31R-2, $145-147 \mathrm{~cm}$

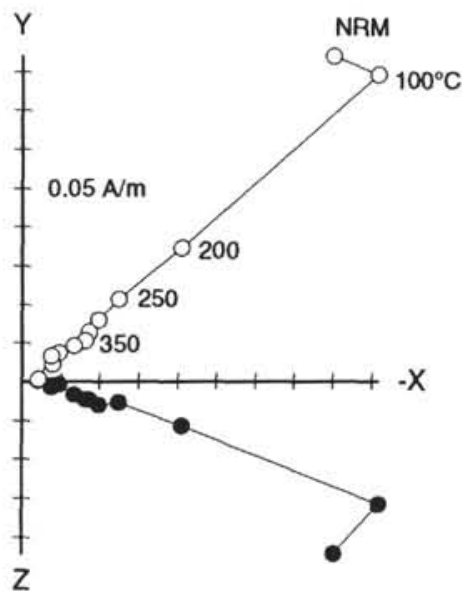

Sample 134-832B-31R-3, $8-10 \mathrm{~cm}$

Figure 8. Examples of TH demagnetization in slumped layers in Core 134-832B-31R. Apparent reversed and normal magnetizations were observed, but in the absence of absolute geographic orientation, interpretation of the magnetization was not straightforward. Symbols and conventions as in Figure 5.
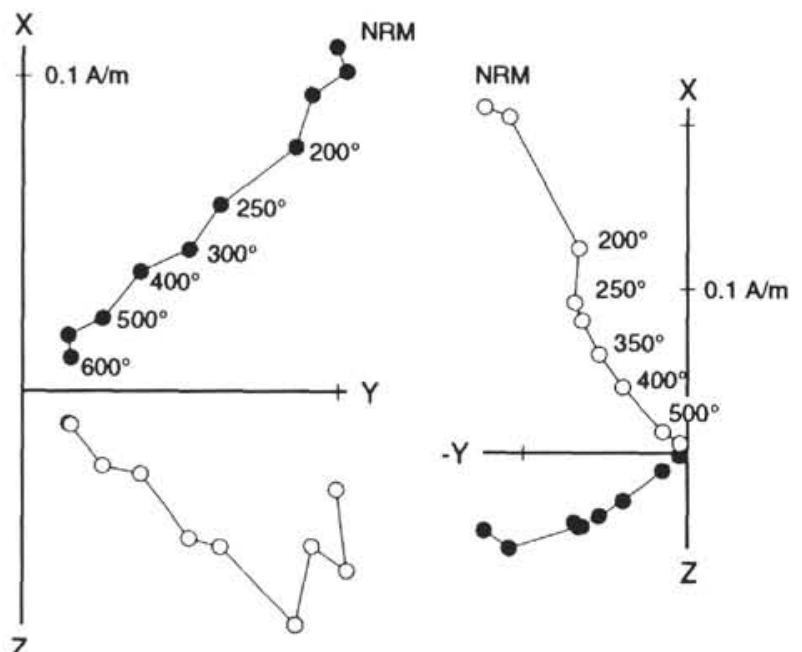

Sample 134-832B-61R-3, $75-77 \mathrm{~cm}$

Sample 134-832B-61R-3, $119-121 \mathrm{~cm}$

Figure 9. Orthogonal diagrams of TH demagnetization from two samples from Core 134-832B-61R showing a reversal of polarity in Section 134-833B-61R-3. Symbols and conventions as in Figure 5.

to about 766 mbsf, the bedding planes dip gently (about $10^{\circ}$ ) and no important structural perturbations occur. Again, the magnetization is complex and the pass-through cryogenic record shows evidence for normal and reversed magnetizations with a clear link to the lithology. $\mathrm{AF}$ and $\mathrm{TH}$ demagnetization data confirm the difficulty in identifying the characteristic primary magnetization. TH demagnetization sometimes reveals clearly a reversed component that was not isolated by $\mathrm{AF}$ (see example for two samples from the same single piece in Core 134-833B-69R demagnetized by $\mathrm{AF}$ and TH, Fig. 13). Despite the difficulty for isolating the primary magnetization accurately, an apparent magnetostratigraphic record was observed in this lithostratigraphic unit (Fig. 14). For the interval from 579 to $658 \mathrm{mbsf}$, all samples clearly indicate a normal polarity. A reversed interval was observed from 660.9 to 668.7 mbsf (from Sections 134-833B-63R-5 to $-64 \mathrm{R}-2$ ), which is defined by both pass-through measurements and data from nine corresponding discrete samples. Another reversed interval occurs in Cores 134-833B-67R to -73R (from 699.2 to 755.2 mbsf). The primary nature of the characteristic component is supported by the reversed polarity throughout this interval. From Core 134-833B-75R (770 mbsf) downward, the polarity pattern is obscured by strong sedimentary structures (such as slumps).

4. Lithostratigraphic Unit V (Cores 134-833B-82R to -99R, 830.3$1001.1 \mathrm{mbsf}$ ) consists of basaltic sills interstratified with some layers of sedimentary rocks. The sedimentary rocks have the same lithology and exhibit magnetic properties similar to those from Cores 134833B-75R to $-81 \mathrm{R}$ of Unit IV, mentioned above.

The NRM intensities of the sills are very high (up to $100 \mathrm{~A} / \mathrm{m}$ ), as are magnetic susceptibilities (Collot, Greene, Stokking, et al., 1992), but they vary among the sills as indicated in the variations of intensity of magnetization after AF demagnetization at $5 \mathrm{mT}$ (Fig. 15). These differences provide evidence for different phases of intrusions. The sills recovered in Cores $134-833 \mathrm{~B}-81 \mathrm{R}$ to $-87 \mathrm{R}$ ( $830-885 \mathrm{mbsf}$ ) have high intensities of magnetization and relatively stable magnetic directions (Fig. 16). Disrupted pieces of silty limestone were found in Core 134-833B-84R that may indicate that there is a boundary between at least two sills. All samples below this boundary, recovered in Cores 134-833B-84R, -85R, -86R, and -87R, have stable magnetic directions with characteristic positive inclinations, which suggests intrusion during a reversed period (Fig. 16). In contrast, all samples in the sill above the disrupted sediment (Cores 134-833B-81R to -84R) have more shallow inclinations upon AF demagnetization (Fig. 16). These shallow inclinations, if not the result of incomplete removal of secondary components, may indicate intrusion at a slightly different time than for the underlying sill unit. Lacking azimuthal orientation, we cannot accurately determine the polarity for these cores: large geomagnetic secular variations may also result in shallow inclinations. Another sill was found in Cores $833 \mathrm{~B}-91 \mathrm{R}$ and $-92 \mathrm{R}$ (910-934 mbsf). The intensity of magnetization is lower and the magnetization is less stable than that observed in the upper sills, but a few samples provide evidence (Fig. 17) indicating intrusion in a reversed period. Results from the lower sills from Core 134-833B-94R down to the bottom of the hole are uncertain. The magnetization in these cores is very soft, as indicated by the AF demagnetization of Sample 134-833B-97R-3, 20-22 cm (Fig.17), one of the most straightforward demagnetization diagrams out of 23 discrete samples taken in this sill.

\section{MAGNETOSTRATIGRAPHY}

As with all applications of magnetostratigraphy, correlation of polarity zones with the GPTS must be formulated in conjunction with 
A

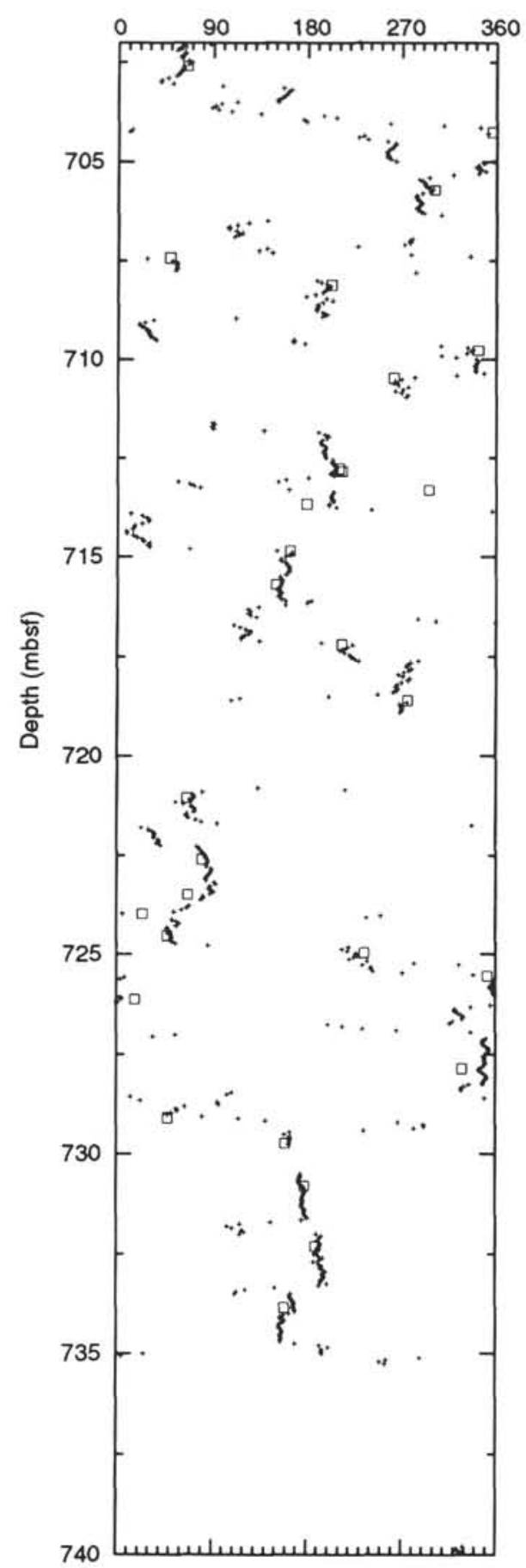

Inclination $\left({ }^{\circ}\right)$

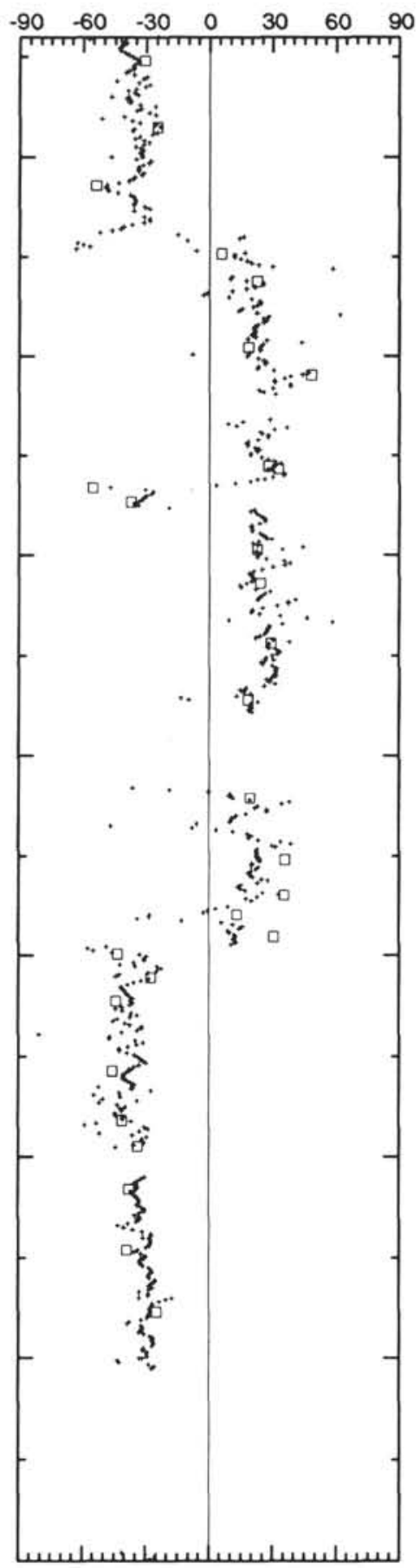

Intensity $(\mathrm{A} / \mathrm{m})$

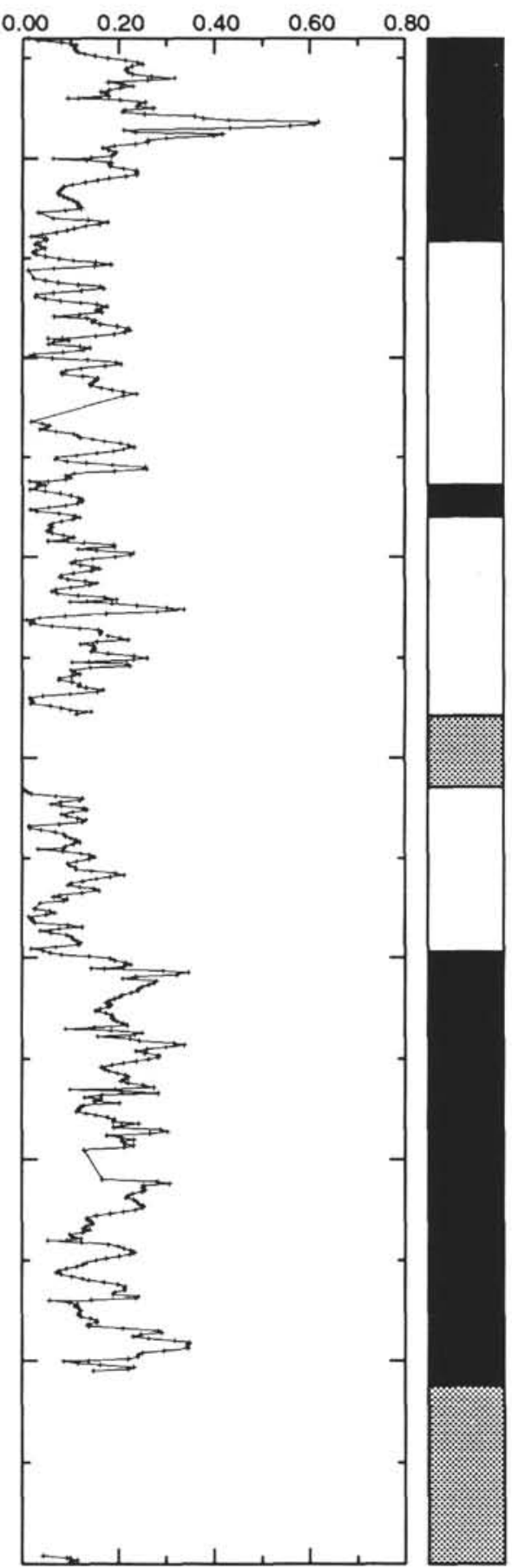

Figure 10. Data obtained using the pass-through cryogenic magnetometer (after $10 \mathrm{mT}$ AF demagnetization) and characteristic directions from discrete samples in three depth intervals from Hole 832 B. A. $702-740$ mbsf. B. 740-770 mbsf. C. $795-825$ mbsf. All covering the Pliocene and late Miocene time. The interpretation of the magnetostratigraphy is also given; zones in black (white) correspond to normal (reversed) polarity, and shaded areas correspond to gaps in the sampling. The plot of the unoriented relative declination is given to highlight the homogeneity of the magnetization within long undisturbed pieces. Reversed magnetization seems to be associated with low intensity of magnetization because of incomplete removal of secondary overprinting at $10 \mathrm{mT}$.

the analyses of all independent age constraints available, in this study this is done primarily from nannofossil and planktonic foraminifer data. We used the chronology of Berggren et al. (1985) as a foundation and correlated magnetozones with the GPTS in the manner that appears most consistent with both the magnetic and biostratigraphic data. In naming the various polarity intervals, we used the familiar proper names for the Pliocene-Pleistocene magnetic chrons (Brunhes, Ma- tuyama, Gauss, and Gilbert) and subchrons (e.g., Jaramillo and Olduvai). Recent radiometric studies using ${ }^{39-40} \mathrm{Ar}$ (Baski et al., 1991) have refined the calibration of the GPTS. Also, Hilgen (1991) recently suggested an astronomical calibration of the GPTS based on the tuning from sapropel paleoclimatic related cycles. These studies are still in progress, and we prefer to stick with the GPTS proposed by Berggren et al. (1985). When constructing a magnetostratigraphy for the two 
B

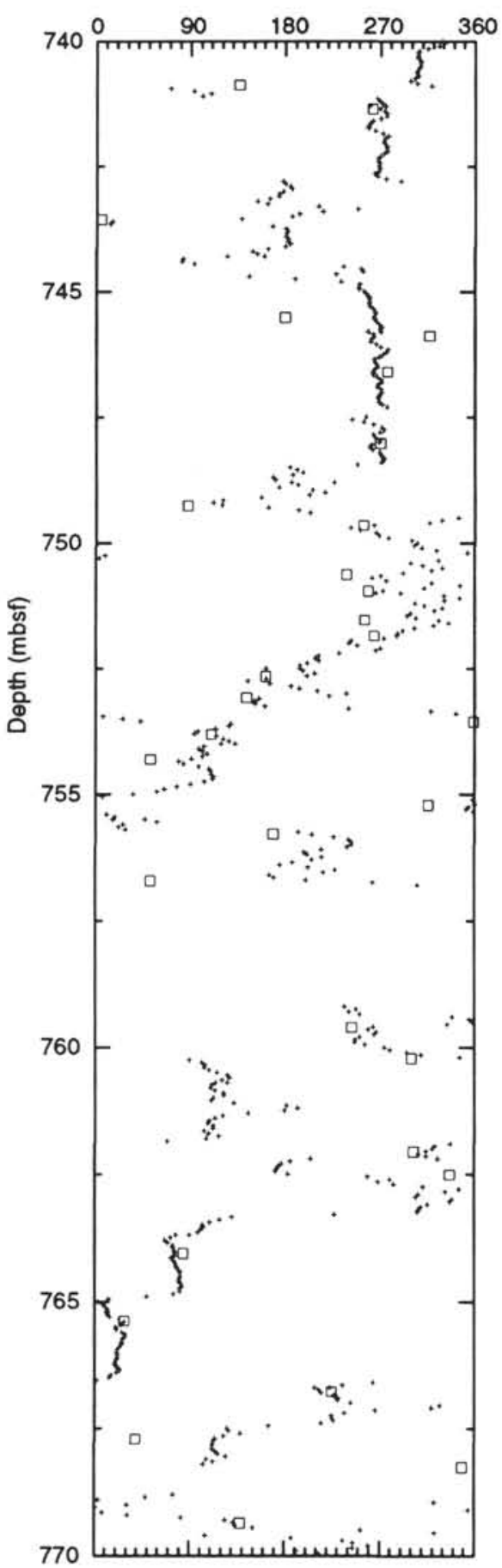

Inclination $\left({ }^{\circ}\right)$

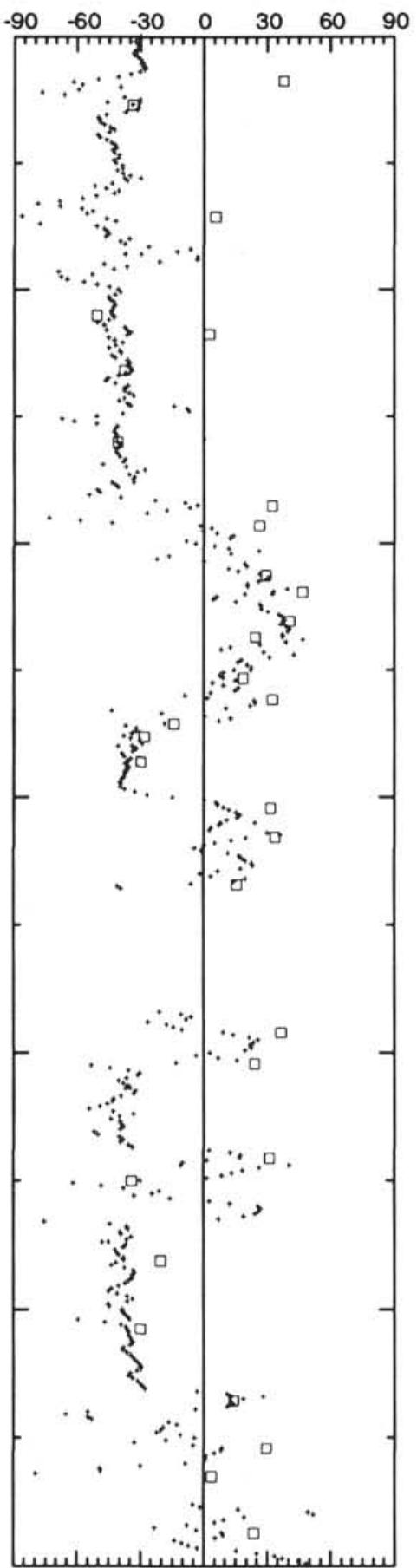

Intensity $(\mathrm{A} / \mathrm{m})$

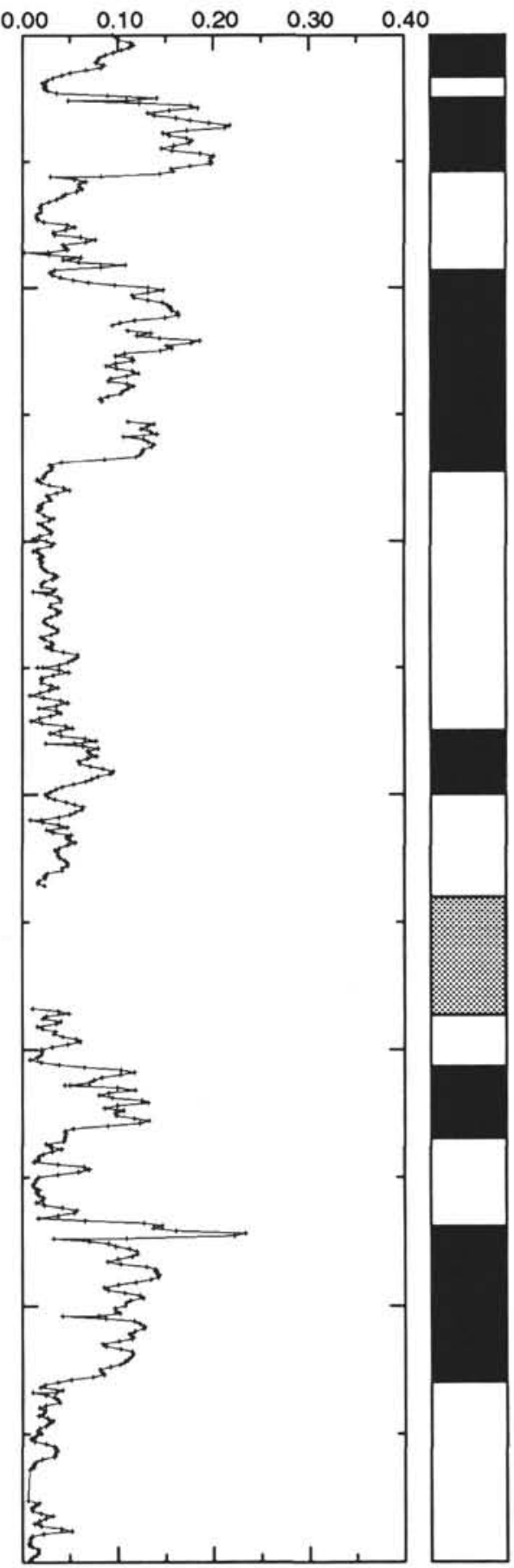

Figure 10 (continued).

sites, results from the fine-grained lithologies (claystone, fine siltstone, and mudstone) were preferentially used because fine-grained sediments acquire depositional remanent magnetization more efficiently than coarser lithologies, and fine-grained sedimentary layers usually have low permeability and are less susceptible to acquisition of secondary chemical remanent magnetization. However, incomplete core recovery and uncertain magnetizations resulting from drilling and viscous overprints impede a straightforward correlation of the observed polarity pattern to the GPTS. The paleomagnetic results previously discussed are summarized in Figure 18 and Table 2.
The characteristic magnetizations observed in Holes 832A and $833 \mathrm{~A}$ are of normal polarity. Biostratigraphic data indicate that the sediment recovered from both holes are of late Pleistocene to Holocene (Zone N22) age. Thus, both paleomagnetic results and biostratigraphy suggest that these sediments were deposited within the Brunhes Chron $(<0.78 \mathrm{Ma})$. Secular variations of geomagnetic field could not be detected from these cores because of the drilling remagnetization. The geomagnetic excursions previously reported in the Brunhes Chron (Champion et al., 1988; Harrison, 1980) also were not observed at these two holes. 
C

Declination $\left({ }^{\circ}\right)$

Inclination $\left({ }^{\circ}\right)$

Intensity $(A / m)$
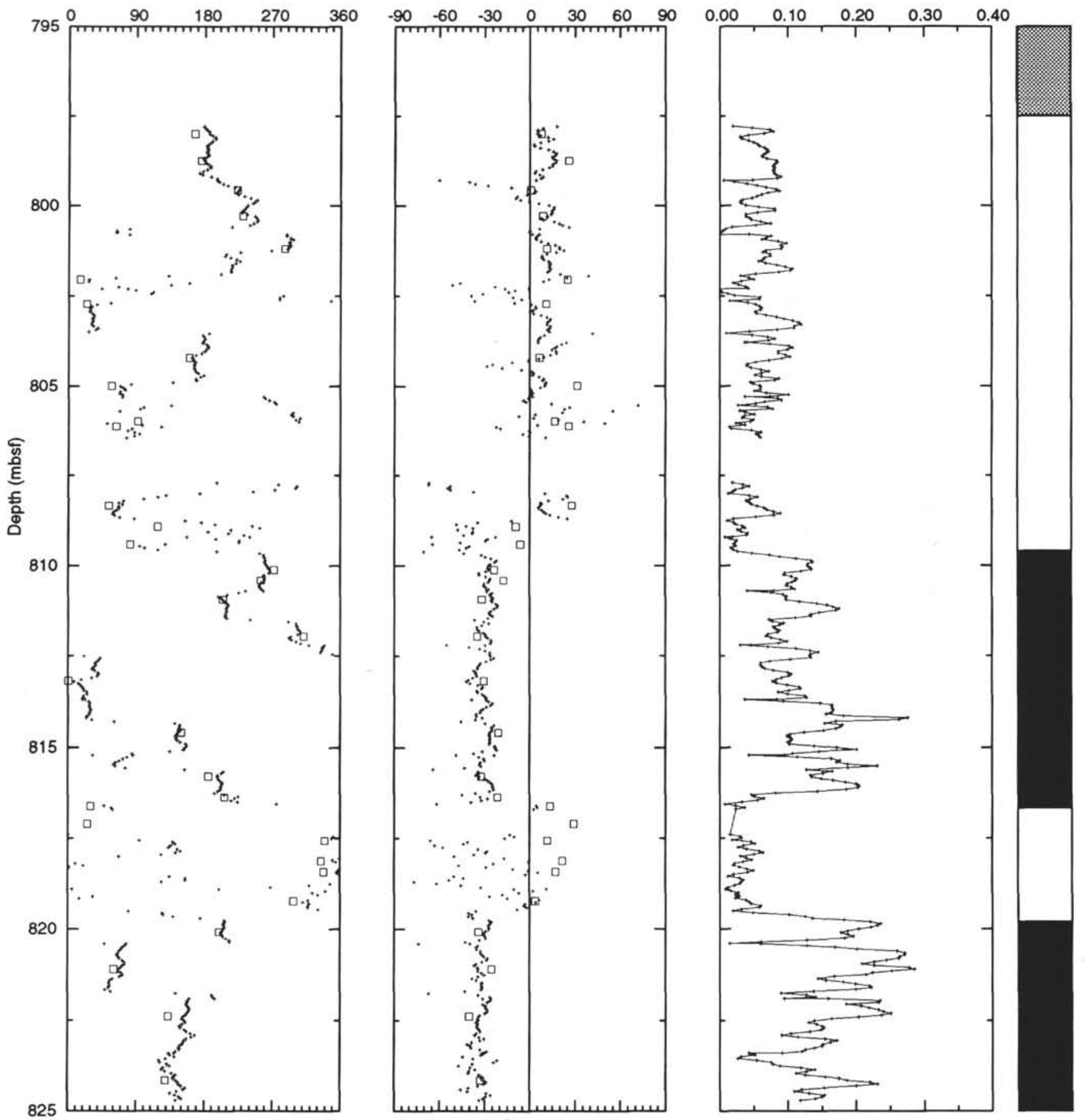

Figure 10 (continued).

\section{Hole 832B}

The Brunhes/Matuyama boundary was not identified in Hole 832B. The first evidence for a reverse magnetization occurs in Core 134832B-26R. Samples between 318.1 and $529.2 \mathrm{mbsf}$ have been assigned to the early Pleistocene based on the co-occurrence of Globorotalia truncatulinoides and Globorotalia tosaensis, but slumps and magnetic overprints prevented a reliable magnetostratigraphic interpretation.

The best magnetostratigraphic record was found in calcareous claystone below the unconformity with the volcanic breccias at 702 mbsf (Fig. 19). The first appearance dating (FAD) of Globorotalia truncatulinoides $(1.9 \mathrm{Ma})$ at $716 \mathrm{mbsf}$ and the last appearance dating (LAD) of D. brouweri (1.89 Ma) at $706 \mathrm{mbsf}$ indicate that the reversal at $707 \mathrm{mbsf}$ should correspond to the lower Olduvai boundary. LAD of D. penaradiatus (2.35 Ma) and LAD of D. surculus (2.42 Ma) occur between 718 and 725 mbsf and constrain the Gauss/Matuyama boundary at $724.7 \mathrm{mbsf}$. The very short normal polarity interval from 713.2 to $713.7 \mathrm{mbsf}$ might represent the record of one of the Réunion events. LAD of $S$. abies ( $3.45 \mathrm{Ma}$ ) is found at 747.7 mbsf near the Gilbert/Gauss boundary at about 748 mbsf, which is expected from 
Paleomagnetic record - Cores 833B-38R and 833B-39R
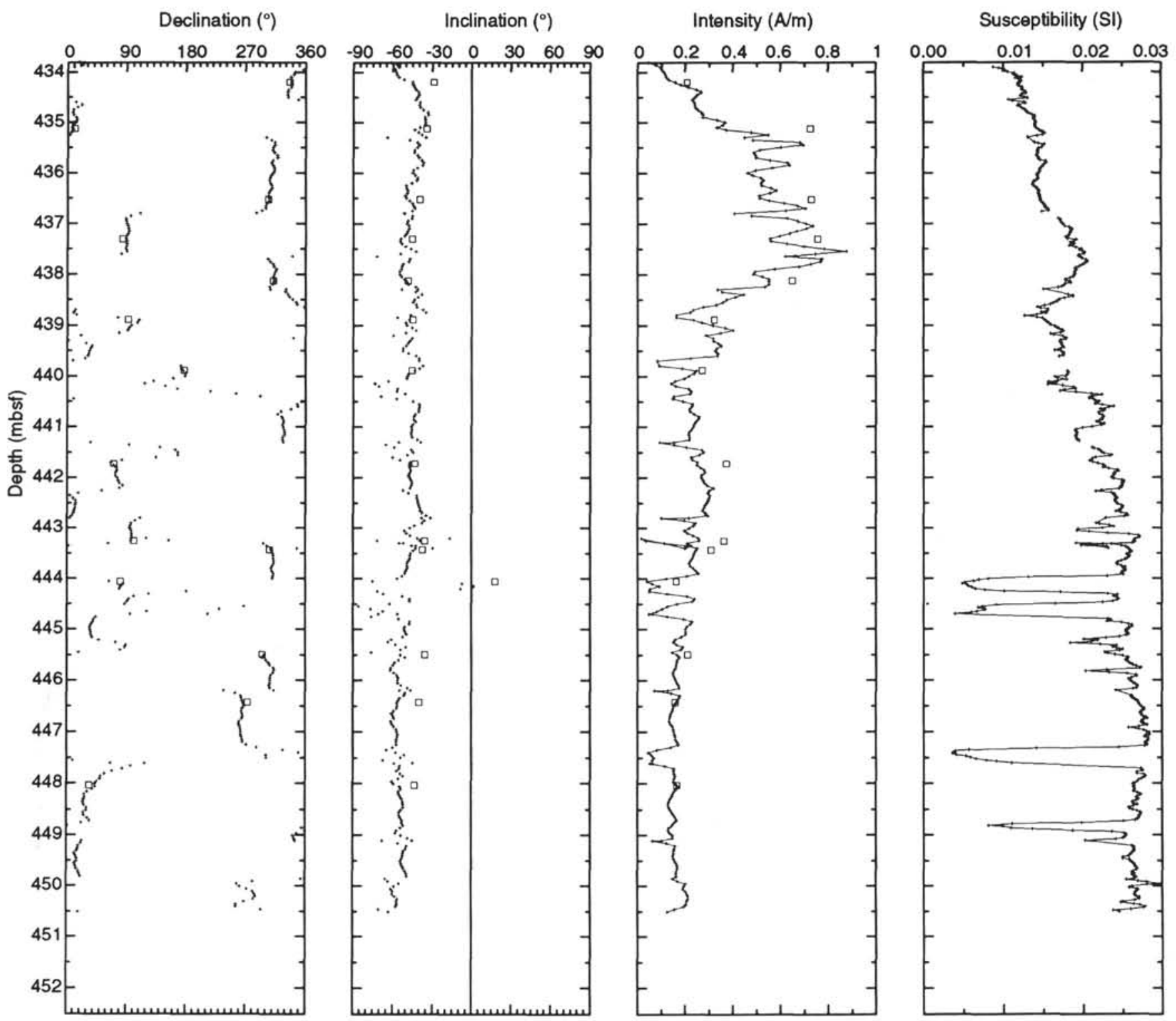

Figure 11. Data obtained using the pass-through cryogenic magnetometer, characteristic magnetization, and susceptibility data from volcanic sandstone from Cores 134-833B-38R and-39R. Sharp contrasts in the susceptibility data correspond to interbedded layers of highly bioturbated chloritic claystone.

the interpretation of the paleomagnetic data. The absence of the planktonic foraminifer Globorotalia crassaformis below $759 \mathrm{mbsf}$ suggests that sediments below that depth were deposited prior to 4.2 $\mathrm{Ma}$, because the FAD of Globorotalia crassaformis occurs generally above the Sidufjall Subchron. Because of poor core recovery and less satisfactory magnetic properties, the magnetostratigraphy is unknown from 770 to 795 mbsf, but the FAD of Globorotalia tumida tumida $(5.2 \mathrm{Ma})$ at about $810 \mathrm{mbsf}$ suggests that the reversal at $810 \mathrm{mbsf}$ corresponds to the boundary between Chron 5 and Gilbert.

\section{Hole 833B}

The first polarity reversal was found in Core 134-833B-14R (202.8 mbsf). Below this depth (to about $375 \mathrm{mbsf}$ ), the inclinations of discrete samples from Cores $134-833 \mathrm{~B}-14 \mathrm{R}$ to $-32 \mathrm{R}$ are predominantly positive (Fig. 18); thus, the interval may correspond to a period of predominantly reversed polarity (Matuyama Chron). Preliminary biostratigraphic evidence also suggests that sediments from Cores 134-833B-
$13 R$ to $-31 R$ are of early Pleistocene age. Thus, the first magnetic polarity shift from normal to reversed observed between Cores 134833B-13R and -14R may represent the Brunhes/Matuyama boundary $(\sim 0.78 \mathrm{Ma})$. A transition from reversed to normal occurs in Core 134-833B-18R and might record the upper limit of the Jaramillo Subchron. Sediments in Core 134-833B-20R are fairly homogeneous, and a reversal from normal to reversed can be identified and may correspond to the lower Jaramillo boundary. The FAD of $P$. finalis $(1.3$ $\mathrm{Ma}$ ) is found at $311 \mathrm{mbsf}$ and is usually midway between the Jaramillo and Olduvai subchrons. Because the magnetization is predominantly reversed from 300 to 375 mbsf, the Olduvai Subchron (and the Pliocene/Pleistocene boundary) should be found lower in the section, but overprints in volcanic sandstone hide primary information. Based on the FAD Globorotalia tosaensis (3.1 Ma) at $646 \mathrm{mbsf}$, the short, well-defined reversed interval from 660 to $670 \mathrm{mbsf}$ might correspond to the Mammoth Subchron. The upper part of the reversed Gilbert Chron might be recorded from 700 to 755 mbsf. Mixed polarities linked to lithological variations and the presence of basaltic sills pre- 


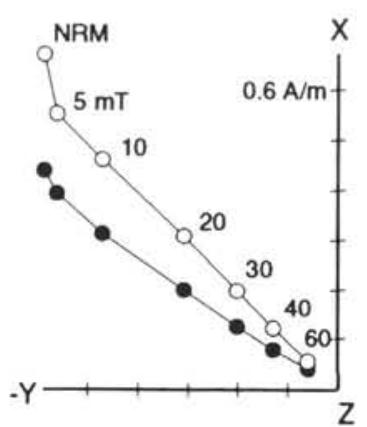

Sample 134-833B-38R-2, $123-125 \mathrm{~cm}$

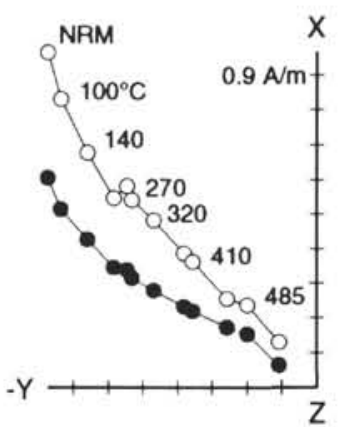

Sample 134-833B-38R-2, $128-130 \mathrm{~cm}$

Figure 12. Example of $\mathrm{AF}$ and $\mathrm{TH}$ demagnetizations in the fine-grained sandstone in Core 134-833B-38R. The apparent high stability of the magnetization would imply a characteristic normal polarity in this core. Symbols and conventions as in Figure 5.

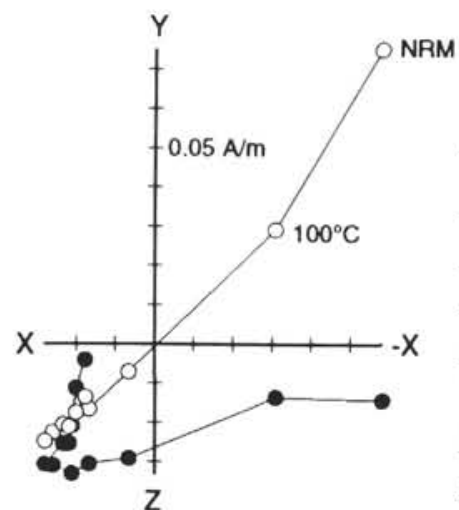

Sample 134-833B-69R-7, $28-30 \mathrm{~cm}$

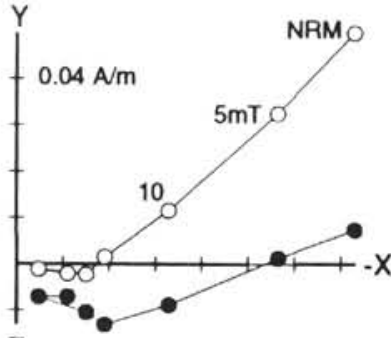

Z

Sample 134-833B-69R-7, $32-34 \mathrm{~cm}$

Figure 13. AF and $\mathrm{TH}$ demagnetizations of two samples from a single piece from Section 134-833B-69R-7. Symbols and conventions as in Figure 5.

Table 2. Paleomagnetic datums, Holes 832B and 833B.

\begin{tabular}{llc}
\hline Paleomagnetic datum & $\begin{array}{l}\text { Age } \\
\text { (Ma) }\end{array}$ & $\begin{array}{c}\text { Depth } \\
\text { (mbsf) }\end{array}$ \\
\hline Hole 832B & & \\
Lower Olduvai & 1.88 & $706.0-707.5$ \\
Gauss-Matuyama & 2.47 & $724.5-725$ \\
Upper Kaena & 2.92 & $740.6-740.8$ \\
Lower Kaena & 2.99 & $741.2-741.4$ \\
Upper Mammoth & 3.08 & $742.5-743.0$ \\
Lower Mammoth & 3.18 & $744.0-745.0$ \\
Gilbert-Gauss & 3.40 & $748.5-749.0$ \\
Upper Cochiti & 3.88 & $753.0-753.5$ \\
Lower Cochiti & 3.97 & $754.8-755.2$ \\
Upper Sidufjall & 4.40 & $760.1-760.4$ \\
Lower Sidufjall & 4.47 & $761.6-761.9$ \\
Upper Thvera & 4.57 & $763.2-763.4$ \\
Lower Thvera & 4.77 & $766.4-766.6$ \\
Chron 5- Gilbert & 5.35 & $808.5-809.5$ \\
R-N 3A & 5.53 & $816.3-816.6$ \\
N-R 3A & 5.68 & $819.3-819.6$ \\
& & \\
Hole 833B & & $196.0-202.8$ \\
Brunhes-Matuyama & 0.73 & $241.9-242.4$ \\
Upper Jaramillo & 0.91 & $260.8-262.2$ \\
Lower Jaramillo & 0.98 & $660.3-660.9$ \\
Upper Mammoth & 3.08 & $697.5-668.0$ \\
Lower Mammoth & 3.18 & $756.0-700.0$ \\
Gilbert-Gauss & 3.40 & \\
Upper Cochiti & 3.88 & \\
\hline
\end{tabular}

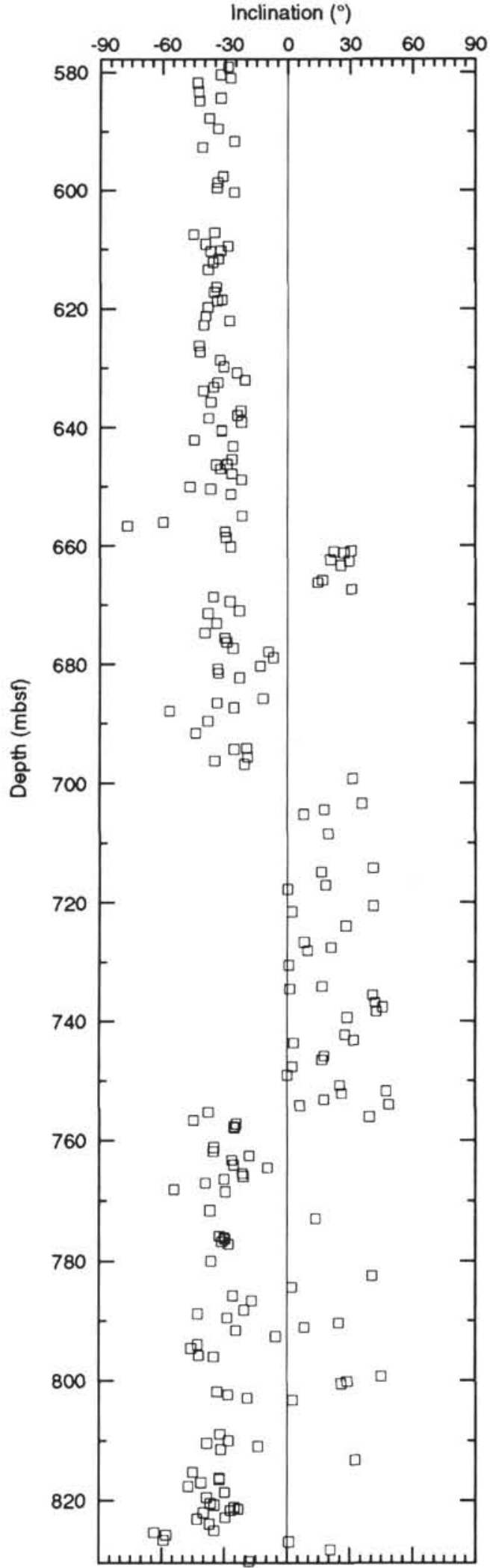

Figure 14. Inclination record from discrete samples in lithostratigraphic Unit IV at Site 833. 


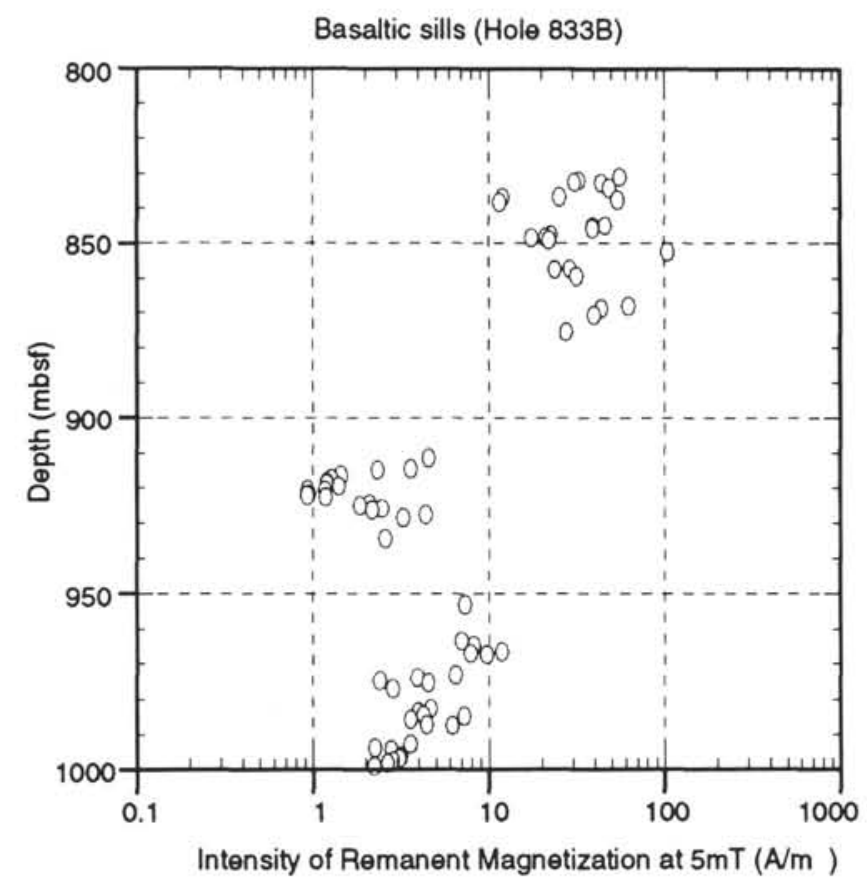

Figure 15. Intensity of the remanent magnetization in basaltic sills at Site 833 . The 5-mT demagnetization level was chosen to reduce the dispersion produced by the drilling-induced overprint.
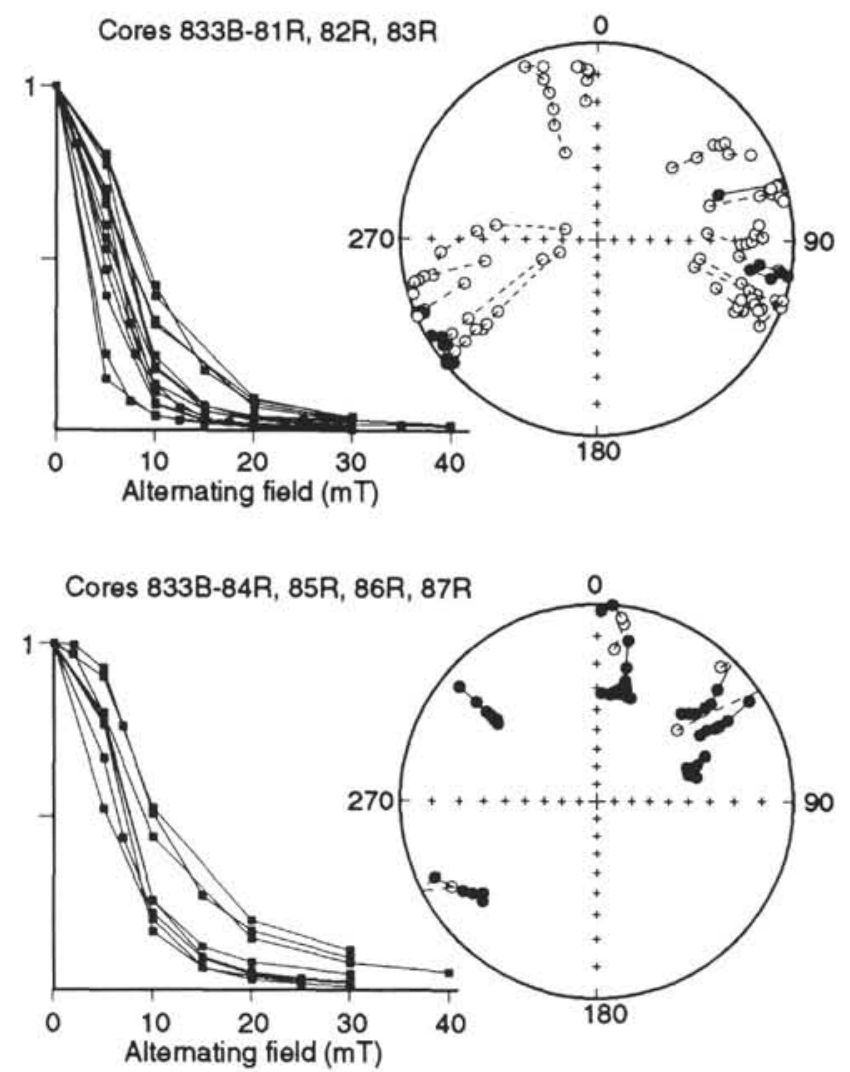

Figure 16. Variations of the normalized intensity with AF peak demagnetization and stereographic projection of AF demagnetization paths from discrete samples of the upper basaltic sills. Samples from Cores $833 \mathrm{~B}-81 \mathrm{R},-82 \mathrm{R}$, and $-83 \mathrm{R}$ have shallower magnetization than those from Cores 833B-84R, -85R, $-86 R$, and $-87 \mathrm{R}$, which is evidence for intrusion and cooling during a reversed polarity period. Open circles $=$ negative inclinations; filled circles $=$ positive inclinations.

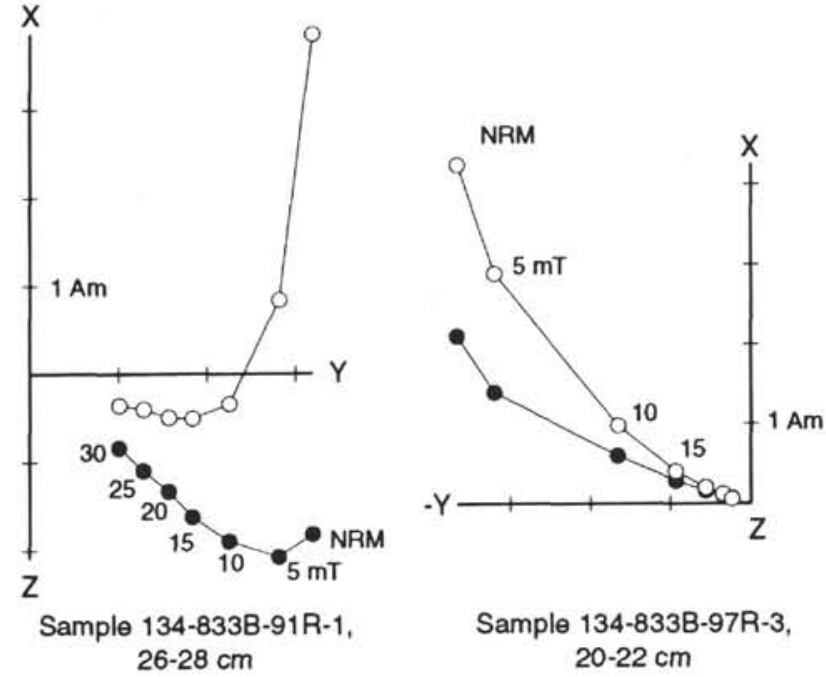

Figure 17. Typical demagnetization diagrams in the lower sills. Symbols and conventions as in Figure 5.

vented the interpretation of the magnetostratigraphic record in the lower part of the hole.

\section{SEDIMENTATION RATE AND CORRELATIONS}

The unconformity at $700 \mathrm{mbsf}$ at Site 832 was interpreted as evidence for the uplift of Espiritu Santo Island in response to the collision of the D'Entrecasteaux Zone (Collot, Greene, Stokking, et al., 1992). Over 700-m of sediment was thus deposited in less than 2 $\mathrm{m} . \mathrm{y}$. while only about $100-\mathrm{m}$ was deposited during the Pliocene. The apparent sedimentation rate was as low as $1.5 \mathrm{~cm} / \mathrm{k} . \mathrm{y}$. during middle Pliocene time, although values for the magnetic susceptibility are still high, from 0.005 to 0.01 SI.

In contrast, the interpretation of the paleomagnetic record from 650 to about $750 \mathrm{mbsf}$ at Site 833 implies a sedimentation rate of about $10 \mathrm{~cm} / \mathrm{k}$.y. during middle Pliocene time. On the other hand, there is no well-defined lithostratigraphic boundary at Site 833 that could correspond to the major unconformity recovered at Site 832 .

However, the sedimentary record at Site 833 can be correlated with onshore geology from the nearby Maewo Island, summarized in Macfarlane et al. (1988). The upper Miocene to lower Pliocene Maewo Group (Bwatigau Formation), composed of submarine volcanics, pillow lavas, and associated intrusions, was not reached at Site 833. However, the Marino Formation at Maewo Island consists of massively bedded gray calcareous mudstone with intercalated coarser beds. Intruding basaltic stocks and sills in the Marino Formation suggest correlations with sediment recovered in the lower part of Hole 833B from 750 to 1000 mbsf. The Nasawa Formation at Maewo Island corresponds to the Pliocene-Pleistocene deposits. These shallow-water deposits consist of white-to-yellow bedded sandstone and mudstone with minor volcanic constituents. In contrast, at Site 833, the magnetic susceptibility record clearly shows a large influx of sediment of volcanic origin throughout the Pliocene. From 750 to 600 mbsf, numerous magnetic susceptibility peaks up to 0.03 SI correlate with a gradual increase in the relative importance of volcanic influxes that may indicate uplift and erosion on nearby volcanic islands. This increase in the importance of sandstone layers during the Pliocene within lithostratigraphic Unit IV suggests a continuous sedimentation process with no unconformity at the transition from Unit IV to III. A normal polarity magnetization is recorded by the sandstone at the transition from litostratigraphic Unit IV to lithostratigraphic Unit III. Viscous overprint associated with late consolidation of the volcanic sandstone is our preferred interpretation for the origin of this magnetization. Another interpretation might be that the sandstone was 
Site 832

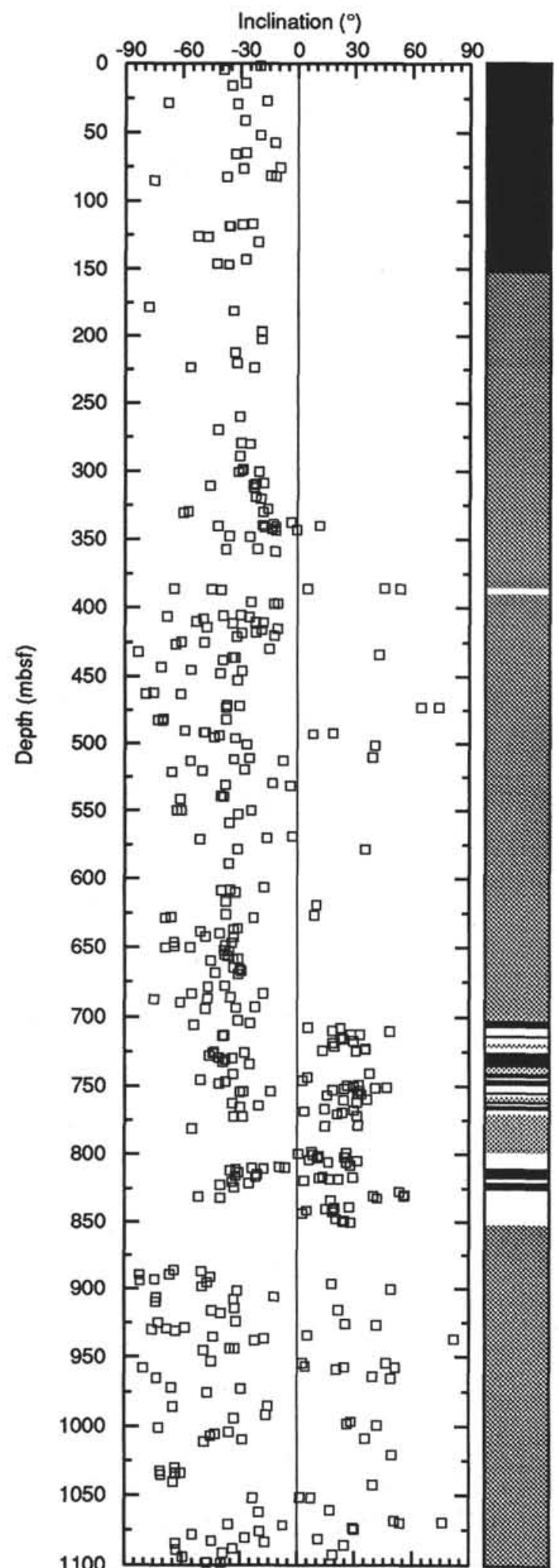

Site $\mathbf{8 3 3}$

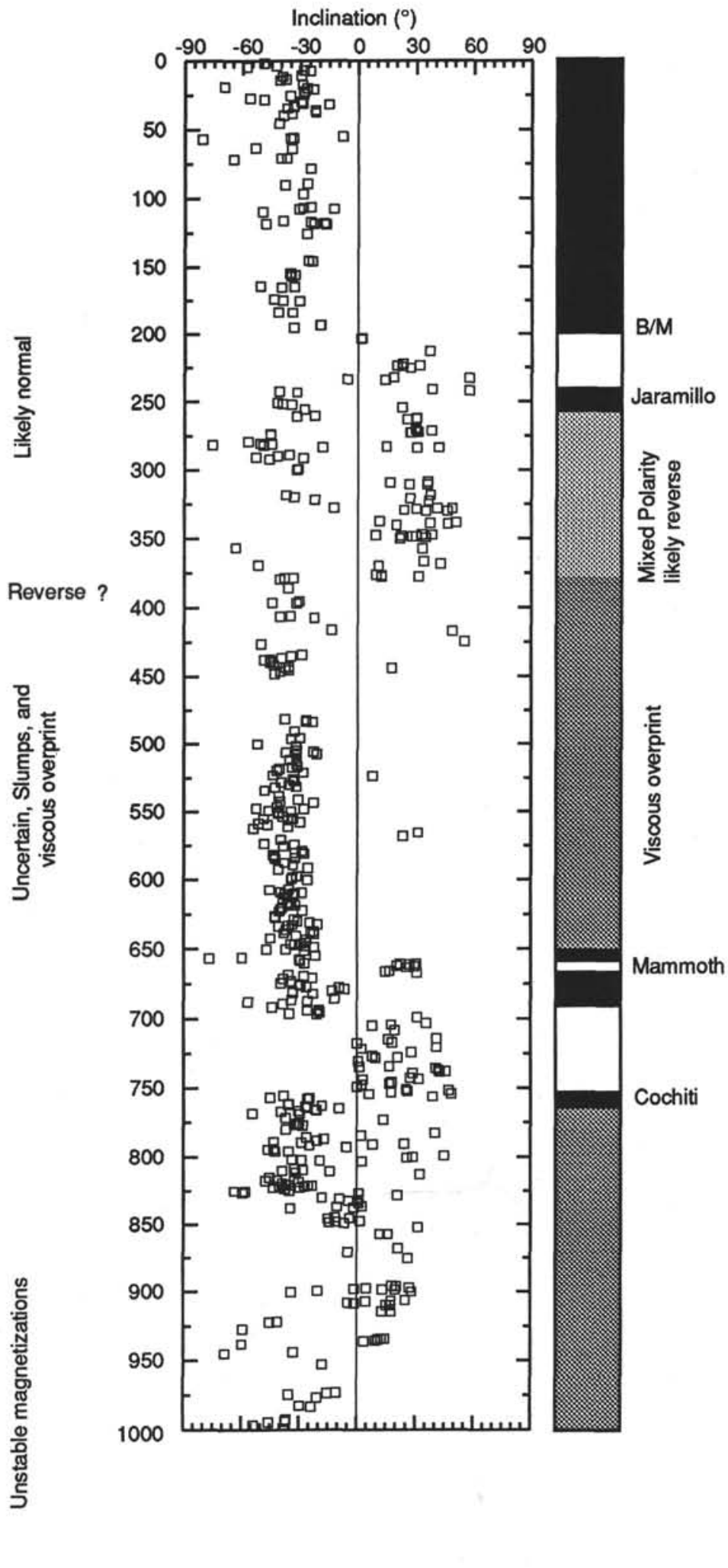

Figure 18. Comparison of the inclination records from discrete samples at Sites 832 and 833 with magnetostratigraphic interpretation. 


\section{Geomagnetic Polarity \\ time-scale}

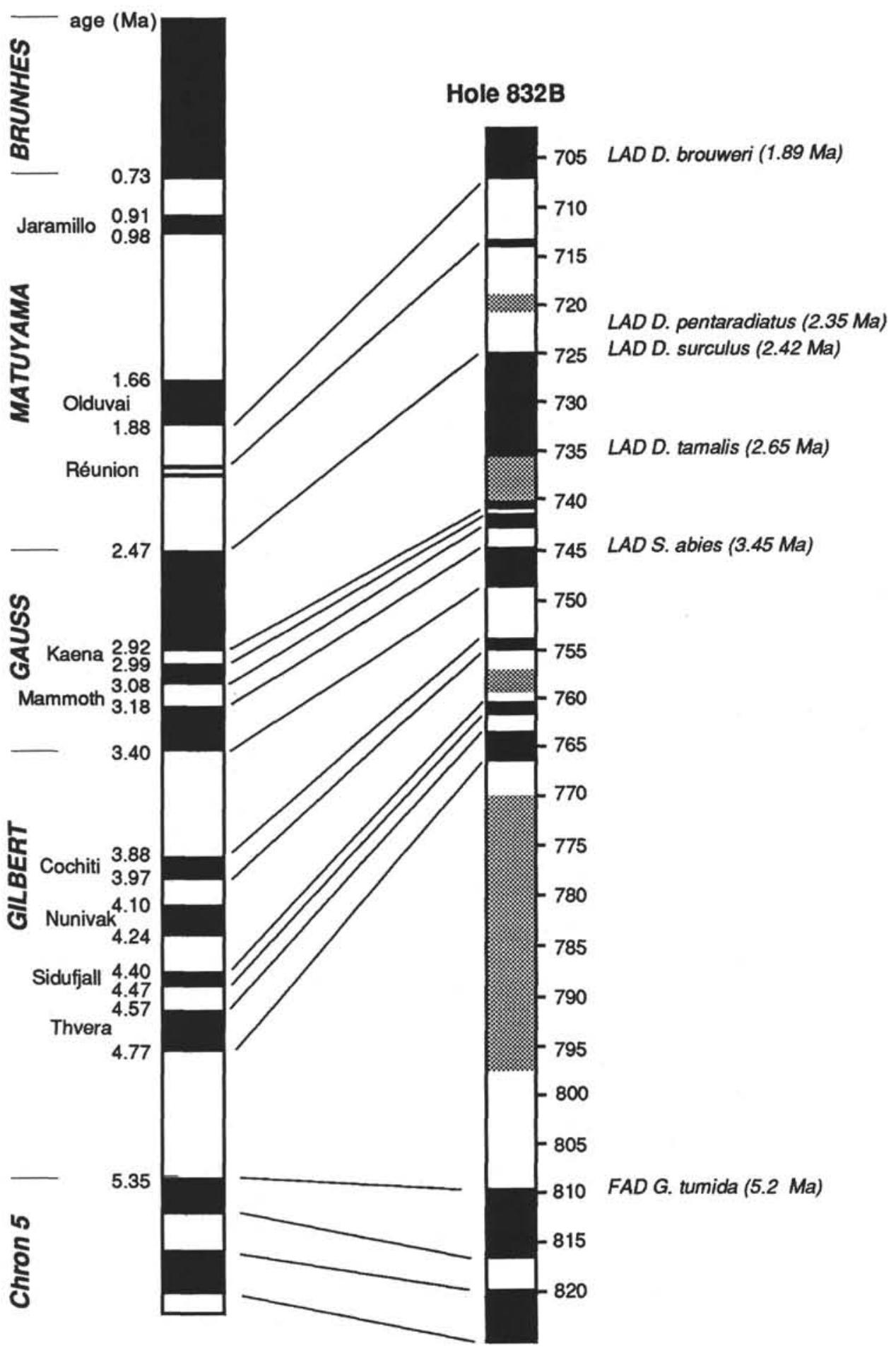

Figure 19. Correlation of the magnetostratigraphic record at Site 832 from 702 to $825 \mathrm{mbsf}$ with the geomagnetic polarity time-scale (Berggren et al, 1985). Black $=$ normal polarity; white $=$ reversed polarity; shading indicates gaps in sampling or uncertain polarities. The key biostratigraphic datums used to constrain this correlation also are shown. $\mathrm{LAD}=$ last appearance datum; $\mathrm{FAD}=$ first appearance datum. 
deposited during a period of normal polarity. At Site 833, deposition during the normal Gauss Chron during late Pliocene time cannot be rejected. However, the normal Olduvai Subchron was not identified, and deposition of the volcanic sandstone during early Pleistocene time correlates with the breccia unit of early Pleistocene age at Site 832. This second hypothesis agrees better with the simultaneous uplifts of the backarc and frontal arc and the subsidence in the Aoba Basin proposed by Collot et al. (1985).

The period from the middle Pliocene to early Pleistocene unfortunately was not accurately recorded in the magnetostratigraphic record in Hole 833B. The magnetostratigraphy cannot constrain the timing of the tectonic events affecting the backarc during this period.

\section{CONCLUSION}

The magnetostratigraphy of the two drilled sites in the North Aoba Basin was seriously limited by the absence of characteristic primary remanent magnetizations in volcanic sandstone. At Site 832, slumps and sedimentary disturbances have reset the initial depositional remanent magnetization above the stratigraphic unconformity marked by a thick breccia layer. However, an almost complete sequence of Pliocene and late Miocene age was recovered from 700 to $850 \mathrm{mbsf}$. The sedimentation rate was low during Pliocene time $(\sim 1.5$ to 2 $\mathrm{cm} / \mathrm{k} . \mathrm{y}$.) compared to a very high accumulation rate $(\sim 35 \mathrm{~cm} / \mathrm{k} . \mathrm{y}$.) during the Pleistocene ( $700 \mathrm{~m}$ in less than $2 \mathrm{Ma}$ ).

At Site 833, the Brunhes/Matuyama boundary and the Jaramillo Subchron were identified from 200 to $260 \mathrm{mbsf}$, indicating an average accumulation rate of about $25 \mathrm{~cm} / \mathrm{k}$.y. during late Pleistocene time. The Pliocene/Pleistocene boundary was not identified at Site 833. Only the middle Pliocene record from the Cochiti to the Kaena subchrons could be recognized at Site 833 . The sedimentation rates during the Pliocene were significantly higher at Site $833(\sim 10 \mathrm{~cm} / \mathrm{k} . \mathrm{y}$.) than those at Site 832 , which implies that the detrital sediments probably were derived from volcanism that occurred along the eastern belt.

\section{ACKNOWLEDGMENTS}

We thank the Ocean Drilling Program for inviting us to participate in Leg 134. The Leg 134 scientific party and technical staff tolerated our extensive sampling and provided valuable insights into the biostratigraphy and sedimentary and tectonic histories. Financial support was provided by a grant from the U.S. Science Advisory Committee.

\section{REFERENCES*}

Baski, A., Houghton, B., McWilliams, M., Tanaka, H., and Turner, G., 1991. What is the age of the Brunhes-Matuyama polarity transition? AGU 1991 Fall Meeting Abstract Vol., 135.
Berggren, W.A., Kent, D.V., and Van Couvering, J.A., 1985. The Neogene: Part 2. Neogene geochronology and chronostratigraphy. In Snelling, N.J. (Ed.), The Chronology of the Geological Record. Geol. Soc. London Mem., 10:211-260.

Champion, D.E., Lanphere, M.A., and Kuntz, M.A., 1988. Evidence for a new geomagnetic reversal from lava flows in Idaho: discussion of short polarity reversals in the Brunhes and Late Matuyama polarity chrons. J. Geophys. Res., 93:11667-11681.

Collot, J.-Y., Daniel, J., and Burne, R.V., 1985. Recent tectonics associated with the subduction/collision of the d'Entrecasteaux zone in the central New Hebrides. Tectonophysics, 112:325-356.

Collot, J.-Y., Greene, H.G., Stokking, L.B., et al., 1992. Proc. ODP, Init. Repts., 134: College Station, TX (Ocean Drilling Program).

Fisher, M.A., Falvey, D.A., and Smith, G.L., 1988. Seismic stratigraphy of the summit basins of the New Hebrides island arc. In Greene, H.G., and Wong, F.L. (Eds.), Geology and Offshore Resources of Pacific Island ArcsVanuatu Region. Circum-Pac. Counc. Energy Miner. Resour., Earth Sci. Ser., 8:201-223.

Greene, H.G., and Johnson, D.P., 1988. Geology of the Central Basin region of the New Hebrides Arc inferred from single-channel seismic-reflection data. In Greene, H.G., and Wong, F.L. (Eds.), Geology and Offshore Resources of Pacific Island Arcs-Vanuatu Region. Circum-Pac. Counc. Energy Miner. Resour., Earth Sci. Ser., 8:177-200.

Harrison, C.G.A., 1980. Secular variation and excursions of the earth's magnetic field. J. Geophys. Res., 85:3511-3522.

Hilgen, F.J., 1991. Astronomical calibration of Gauss to Matuyama sapropels in the Mediterranean and implication for the Geomagnetic Polarity Time Scale. Earth Planet. Sci. Lett., 104:226-244.

Kirschvink, J.L., 1980. The least-squares line and plane and analysis of palaeomagnetic data. Geophys. J. R. Astron. Soc., 62:699-718.

Macfarlane, A., Carney, J.N., Crawford, A.J., and Greene, H.G., 1988. Vanuatu-a review of the onshore geology. In Greene, H.G., and Wong, F.L. (Eds.), Geology and Offshore Resources of Pacific Island Arcs-Vanuatu Region. Circum-Pac. Counc. Energy Miner. Resour., Earth Sci. Ser., 8:45-91.

Schneider, D.A., and Kent, D.V., 1990. Paleomagnetism of Leg 115 sediments: implications for Neogene magnetostratigraphy and paleolatitude of the Réunion hotspot. In Duncan, R.A., Backman, J., Peterson, L.C., et al., Proc. ODP, Sci. Results, 115: College Station, TX (Ocean Drilling Program), 717-736.

Zijderveld, J.D.A., 1967. AC demagnetization of rocks: analysis of results. In Collinson, D.W., Creer, K.M., and Runcorn, S.K. (Eds.), Methods in Palaeomagnetism: New York (Elsevier), 254-286.

Abbreviations for names of organizations and publications in ODP reference lists follow
the style given in Chemical Abstracts Service Source Index (published by American Chemical Society).

Date of initial receipt: 9 May 1992

Date of acceptance: 16 June 1993

Ms 134SR-025 